\title{
Protocol for Development of Authorized Release Limits for Concrete at U.S. Department of Energy Sites
}

Environmental Assessment Division Argonne National Laboratory

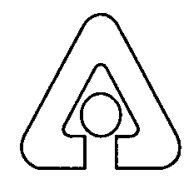

Operated by The University of Chicago, under Contract W-31-109-Eng-38, for the United States Department of Energy 


\section{Argonne National Laboratory}

Argonne National Laboratory, with facilities in the states of Illinois and Idaho, is owned by the United States Government and operated by The University of Chicago under the provisions of a contract with the Department of Energy.

This technical memorandum is a product of Argonne's Environmental Assessment Division (EAD). For information on the division's scientific and engineering activities, contact:

Director, Environmental Assessment Division

Argonne National Laboratory

Argonne, Illinois 60439-4815

Telephone (630) 252-3107

Presented in this technical memorandum are preliminary results of ongoing work or work that is more limited in scope and depth than that described in formal reports issued by the EAD.

Publishing support services were provided by Argonne's Information and Publishing Division (for more information, see IPD's home page: http://www.ipd.anl.gov/).

\section{Disclaimer}

This report was prepared as an account of work sponsored by an agency of the United States Government. Neither the United States Government nor any agency thereof, nor The University of Chicago, nor any of their employees or officers, makes any warranty, express or implied, or assumes any legal liability or responsibility for the accuracy, completeness, or usefulness of any information, apparatus, product, or process disclosed, or represents that its use would not infringe privately owned rights. Reference herein to any specific commercial product, process, or service by trade name, trademark, manufacturer, or otherwise does not necessarily constitute or imply its endorsement, recommendation, or favoring by the United States Government or any agency thereof. The views and opinions of document authors expressed herein do not necessarily state or reflect those of the United States Government or any agency thereof, Argonne National Laboratory, or The University of Chicago. 


\section{Protocol for Development of Authorized Release Limits for Concrete at U.S. Department of Energy Sites}

by J. Arnish, S. Kamboj, S.-Y. Chen, F.L. Parker, ${ }^{*}$ A.M. Smith, ${ }^{*}$ R.H. Meservey, ${ }^{*}$ and J.L. Tripp*

Environmental Assessment Division

Argonne National Laboratory, 9700 South Cass Avenue, Argonne, Illinois 60439

July 2000

Work sponsored by U.S. Department of Energy, Office of Environmental Management, Office of Project Completion, Deactivation and Decommissioning Focus Area

${ }^{*}$ Parker is affiliated with Vanderbilt University, Nashville, Tennessee, and Smith, Meservey, and Tripp are affiliated with Idaho National Engineering and Environmental Laboratory, Environmental Remediation Technologies, Idaho Falls, Idaho. 
This report is printed on recycled paper. 


\title{
Letter Report
}

PROTOCOL FOR DEVELOPMENT OF AUTHORIZED

RELEASE LIMITS FOR CONCRETE AT

U.S. DEPARTMENT OF ENERGY SITES

by

J. Arnish, S. Kamboj, and S.Y. Chen Environmental Assessment Division

Argonne National Laboratory

Frank L. Parker

Vanderbilt University

\author{
A.M. Smith, R. H. Meservey, and J.L. Tripp \\ Environmental Remediation Technologies \\ Idaho National Engineering \& Environmental Laboratory \\ for \\ U.S. Department of Energy
}

July 7, 2000 


\section{CONTENTS}

NOTATION

vi

ABSTRACT

1 INTRODUCTION

2.1 Characterize Property and Prepare a Description .............................................. 7

2.2 Determine Whether Applicable Authorized or Supplemental Limits Exist ........ 10

2.3 Define Authorized or Supplemental Limits as Needed ................................... 12

2.4 Develop Authorized or Supplemental Limits ..................................................... 12

2.4.1 Alternative A: Decontaminate, Crush, and Reuse .................................. 13

2.4.2 Alternative B: Crush and Reuse without Decontamination..................... 15

2.4.3 Alternative C: Decontaminate, Demolish, and Dispose at Nonradiological Landfill or Reuse as Backfill ..................................... 15

2.4.4 Alternative D: Demolish and Dispose at Nonradiological Landfill or Reuse as Backfill ........................................................................ 16

2.4.5 Alternative E: Demolish and Dispose at a Low-Level Waste Facility ...................................................................................... 17

2.4.6 Alternative F: Decontaminate and Reuse Building .............................. 17

2.4.7 Alternative G: Entomb .................................................................. 19

2.4.8 Summary of Results from the Alternatives.............................................. 19

2.4.9 Proposed Authorized Release Limits....................................................... 19

2.5 Compile and Submit Application for DOE Operations Office Approval............ 20

2.6 Document Approved Limits in the Public Record............................................... 21

$2.7 \quad$ Implement Approved Limits.............................................................................. 21

2.8 Conduct Surveys/Measurements..................................................................... 22

$2.9 \quad$ Verify That Concrete Material Meets Release Limits .......................................... 22

$2.10 \quad$ Release Concrete....................................................................................... 22

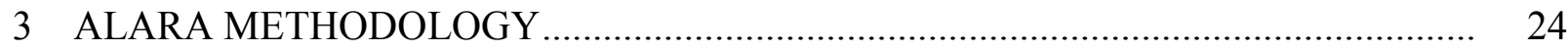

$3.1 \quad$ Unit-Cost Factors .................................................................................... 24

$3.2 \quad$ Unit-Dose Factors .................................................................................... 24

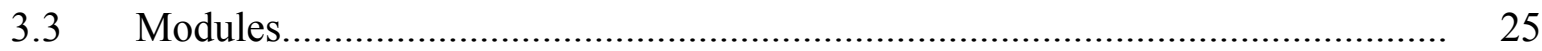

3.3.1 Decontamination ........................................................................ 26

3.3.1.1 Decontamination Efficiency …………………....................... 26

3.3.1.2 Waste Generation................................................................... 27

3.3.1.3 Decontamination Costs .......................................................... 28

3.3.2 Demolition/Crushing........................................................................... $\quad 30$ 


\section{CONTENTS (Cont.)}

3.3.3 Packaging/Transportation ................................................................. 31

3.3.3.1 Packaging/Transportation Costs ............................................ 32

3.3.3.2 Transportation Dose - Driver Scenario .................................... 35

3.3.3.3 Transportation Dose to Persons along the Transportation

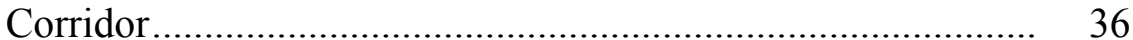

3.3.4 Reuse

3.3.4.1 Construction Worker Scenario............................................... 37

3.3.4.2 Building Reuse Scenario.......................................................... 38

3.3.5 Disposal/Entombment................................................................. 39

3.3.5.1 Disposal Costs.................................................................... 39

3.3.5.2 Landfill Worker .................................................................. 40

3.3.5.3 Future Resident ............................................................ 40

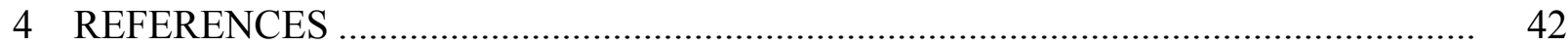

APPENDIX A: Authorized Release Application ......................................................... A-1

APPENDIX B: Decontamination Module ………………......................................... B-1

APPENDIX C: Transportation Unit-Cost and Dose Factors ............................................... C-1

APPENDIX D: Reuse Module Unit-Dose Factors …………............................................ D-1

APPENDIX E: Disposal Module Unit-Dose Factors ……………………………............. E-1

\section{TABLES}

2.1 Surface Activity Guidelines — Allowable Total Residual Surface Activity................ 11

3.1 Comparison of Concrete Disposition Alternatives and the Corresponding Cost and Dose Assessment Modules.

B.1 Common Decontamination Technologies with Unit-Cost and Process Factors for Removal of "Loose" Contamination

B.2 Common Technologies for Removing "Fixed" and Subsurface Contamination from Concrete 


\section{TABLES (Cont.)}

C.1 Volumes and Unit Costs for Selected Cargo Containers ........................................ C-3

C.2 Unit Costs for Concrete Shipments as a Function of Cargo and Transportation Mode.

C.3 Unit-Dose Factors from the Transportation Module for the Driver and Persons Living along or Sharing the Transportation Corridor

D.1 Unit-Dose Factors for the Construction Worker and Building Resident from the Reuse Module

D-3

E.1 Unit-Dose Factors for the Landfill Worker and Future Resident E-3

\section{FIGURE}

2.1 Authorized Release Process Flow Diagram 


\section{NOTATION}

$\begin{array}{ll}\text { ALARA } & \text { as low as reasonably achievable } \\ \text { CFR } & \text { Code of Federal Regulations } \\ \mathrm{cm} & \text { centimeter(s) } \\ \mathrm{cm}^{2} & \text { square centimeter(s) } \\ \mathrm{cm}^{3} & \text { cubic centimeter(s) } \\ \mathrm{D} \& \mathrm{D} & \text { decontamination and decommissioning } \\ \mathrm{DOC} & \text { U.S. Department of Commerce } \\ \mathrm{DOE} & \text { U.S. Department of Energy } \\ \mathrm{dpm} & \text { disintegration(s) per minute } \\ \mathrm{EH} & \text { Office of the Assistant Secretary for Environment, Safety and Health (DOE) } \\ \mathrm{ft} & \text { foot (feet) } \\ \mathrm{ft}^{2} & \text { square foot (feet) } \\ \mathrm{ft} & \text { cubic foot (feet) } \\ \mathrm{g} & \text { gram(s) } \\ \mathrm{h} & \text { hour(s) } \\ \mathrm{kg} & \text { kilogram(s) } \\ \mathrm{km} & \text { kilometer(s) } \\ \mathrm{lb} & \text { pound(s) } \\ \mathrm{LLW} & \text { low-level waste } \\ \mathrm{m} & \text { meter(s) } \\ \mathrm{m}^{2} & \text { square meter(s) } \\ \mathrm{m}^{3} & \text { cubic meter(s) } \\ \mathrm{MEI} & \text { maximally exposed individual } \\ \mathrm{mi} & \text { mile(s) } \\ \mathrm{mrem} & \text { millirem } \\ \mathrm{MT} & \text { metric ton(s) } \\ \mathrm{NRC} & \text { U.S. Nuclear Regulatory Commission } \\ \mathrm{pCi} & \text { picocurie(s) } \\ \mathrm{yd} & \text { yard(s) } \\ \mathrm{yd} & \text { square yard(s) } \\ \mathrm{yd} & \text { cubic yard(s) } \\ \mathrm{yr} & \text { year(s) } \\ & \end{array}$




\title{
PROTOCOL FOR DEVELOPMENT OF AUTHORIZED RELEASE LIMITS FOR CONCRETE AT U.S. DEPARTMENT OF ENERGY SITES
}

by

\author{
J. Arnish, S. Kamboj, S.-Y. Chen, F.L. Parker, \\ A.M. Smith, R.H. Meservey, and J.L. Tripp
}

\begin{abstract}
The purpose of this protocol is to assist U.S. Department of Energy (DOE) sites in releasing concrete for reuse. Current regulations allow the sites to release surface-contaminated materials if their radioactivity falls below certain levels and to possibly release materials with volumetric contamination or higher levels of surface contamination on a case-by-case basis. In all cases, an ALARA (as low as reasonably achievable) analysis that evaluates the risks of releasing volumetrically contaminated concrete or concrete with higher levels of surface contamination is required as a basis for proposing and setting new release limits that allow for reuse of the concrete material.

To evaluate the dose impacts of reusing radioactively contaminated material, the measured radiation levels $(\mathrm{pCi} / \mathrm{g}$ or disintegrations per minute $[\mathrm{dpm}] / 100 \mathrm{~cm}^{2}$ ) must be converted to the estimated dose (mrem/yr) that would be received by affected individuals. The dose depends on the amounts and types of isotopes present and the time, distance, and method of exposure (e.g., inhalation or external exposure). For each disposition alternative, the protocol provides a systematic method to evaluate the impact of the dose on the affected individuals. The cost impacts of reusing concrete also need to be evaluated. They too depend on the disposition alternative and the extent and type of contamination.
\end{abstract}

The protocol provides a method to perform a detailed analysis of these factors and evaluate the dose and cost impacts for various disposition alternatives. Once the dose and cost impacts of the various alternatives have been estimated, the protocol outlines the steps required to propose new release standards that allow release and reuse of the concrete material. 


\section{INTRODUCTION}

Within the next few decades, millions of cubic meters of concrete will be removed from nuclear facilities across the U.S. Department of Energy (DOE) complex as a result of decontamination and decommissioning (D\&D) activities. One of the challenges facing DOE's D\&D program is to find ecologically and economically sound methods to deal with the large volume of potentially radiologically contaminated concrete that will be generated.

Releases of material containing residual radioactivity have been ongoing within DOE for a few years, but these releases have been limited to materials with surface contamination. Explicit release levels have been prescribed for surface-contaminated materials in DOE Order 5400.5, "Radiation Protection of the Public and Environment" as amended, which was first issued on February 8, 1990 (DOE 1990). No equivalent release levels for materials with volumetric contamination are currently established. Because of this lack of explicit release standards, a process of "authorized" release for volumetrically contaminated material is permitted under the existing Order 5400.5 and the proposed rule in Title 10, Part 834 of the Code of Federal Regulations (10 CFR Part 834). Authorized release is based on a case-by-case (but systematic) approach that provides for the development of authorized release limits through a series of prescribed steps before approval for release is granted. Specific requirements include the following: (1) pertinent radiological characteristics are identified and specified for the materials, (2) release limits are derived to meet the as-low-as-reasonably-achievable (ALARA) objectives, (3) requisite documentation is completed and approved by DOE authorities, and (4) concurrence by appropriate stakeholders is sought and obtained.

To further clarify the provisions and to implement the policy of authorized release, the draft handbook entitled Controlling Release for Reuse or Recycle of Property Containing Residual Radioactive Material was published by DOE in 1997. The Handbook has been distributed throughout DOE field offices for interim use and implementation (Chen et al. 1999).

The release process prescribed in the Handbook applies only to non-real DOE property for which the preferred future use involves reuse or recycle. In general, real property includes real estate and facilities, while non-real property includes removable items such as those listed below. Release occurs when the property is transferred out of DOE control by sale, lease, gift, or other disposition, provided that the property does not remain under the radiological control of DOE, the U.S. Nuclear Regulatory Commission (NRC), or a responsible Agreement State. The release does not apply to real property, radioactive wastes, soils, liquid discharges, or gaseous or radon emissions. Examples of categories of property that are covered include:

- Consumable items such as wood, containers, labware, and paper;

- Personal items such as clothing, brief cases, bags, respirators, and gloves; 
- Office items such as computers, telecommunication equipment, unused office supplies, and furniture;

- Tools or equipment such as hand tools, construction machinery, vehicles, tool boxes, ladders, and scales; and

- Scrap materials such as wood, tanks, scrap metals, concrete, wiring, doors, and windows.

The authorized release approach described in the Handbook for non-real property consists of 10 steps that address the general areas of property characterization, evaluation and development of authorized limits, approval of release, verification, and implementation of release. It is important to note that authorized or supplemental limits may be derived for individual releases of non-real property (e.g., one-time sale of reusable copper wire), or for major categories of non-real property (e.g., scrap metal or office machines) that are routinely released over time. In the latter case, once authorized limits (or supplemental limits [which apply only to special conditions]) have been approved for a category, individual releases of non-real property within that category are assumed to meet ALARA requirements if compliance with the limits has been demonstrated. Therefore, the entire 10-step process is not necessarily required for each proposed release. Determining the possible existence of previously established authorized or supplemental limits applicable to the proposed release is addressed early in the 10 -step process. The 10 major steps of the release process for non-real property are as follows:

1. Characterize property and prepare a description.

2. Determine whether applicable authorized or supplemental limits already exist.

3. Define authorized or supplemental limits needed.

4. Develop authorized or supplemental limits.

5. Compile and submit application for DOE Operations Office approval.

6. Document approved limits in the public record.

7. Implement approved limits.

8. Conduct surveys/measurements. 
9. Verify that applicable authorized or supplemental limits have been met.

10. Release property.

The Handbook recommends actions to guide field personnel in implementing each step and provides detailed instructions and examples for some steps.

In upcoming years, numerous DOE facilities will require decommissioning. These activities will generate large volumes of concrete materials as facilities are dismantled. These facilities will include storage, process, and office buildings with concrete foundations, floors, and, in some cases, walls. In addition, in some cases, concrete pads, basins, and channels will need to be considered. Therefore, a protocol for developing authorized release limits for concrete materials needs to be implemented.

Protocols for developing authorized release limits for the reinforcement bars (rebar) contained in concrete have already been developed [P2Pro(RSM)] and are available in computerized form (Arnish et al. 1999). The protocols described in this report are designed to assist in obtaining authorization to release the concrete materials from DOE control. Decision steps containing appropriate protocols are developed to guide the user through the 10-step process stipulated in the Handbook by using different options to reach a screening decision. Section 2 of this document describes the authorized release process and provides the user with the information required to implement the protocols. Section 3 contains the methodology to estimate the costs and radiological impacts associated with each alternative in the ALARA analysis. A copy of the application form for the development of authorized release limits for concrete is provided in Appendix A. Information on unit-cost factors, unit-dose factors, and other details for the decontamination, transportation, reuse, and disposal modules is presented in Appendices B, C, D, and E, respectively.

It should be noted that DOE Order 5400.5 and 10 CFR Part 834 prohibit the release of DOE non-real property (in this case the concrete material) unless the following actions have been undertaken to protect the public and environment:

1. The concrete material has been appropriately surveyed/measured to identify and characterize its radiological condition;

2. Residual radioactive material on concrete material surfaces or interior has been determined to meet acceptable release limits;

3. Required documentation has been completed; and 
4. The owner or recipient of the released concrete material has been appropriately notified of the radiological status of the property and the availability of required documentation.

Before releasing concrete material for reuse, the responsible DOE or contractor personnel must verify that these conditions have been met. Additionally, the responsible personnel must ensure compliance with other applicable laws, regulations, and policies that may not be covered in these protocols. When compliance has been verified and documented, the concrete material may be released. 


\section{AUTHORIZED RELEASE PROTOCOL FOR CONCRETE}

This section provides an overview of the authorized release process and presents the protocol for developing authorized release limits for concrete. A form referred to as the authorized release application (presented in Appendix A) is used to take the user through the necessary steps. The specific step of the application being discussed is highlighted in bold italic text in the following discussion. The methodologies that the user will apply to estimate the costs and radiological doses associated with the alternatives described in this section are provided in Section 3. Figure 2.1 shows a flow diagram for the entire authorized release process.

\subsection{CHARACTERIZE PROPERTY AND PREPARE A DESCRIPTION}

The first step of the authorized release process is to characterize the property and prepare descriptions of the concrete's physical properties and radiological history. The description of the concrete's physical properties should include:

1. Amount of concrete proposed for release

2. Prior use of the concrete
a. Foundations
b. Floors
c. Walls
d. Pads
e. Basins
f. Channels
g. Other

This information should be provided in Step 1, box 1a of the application.

A written radiological history of the concrete should be developed on the basis of process knowledge. In some circumstances, it may be advisable to document the radiological history to 


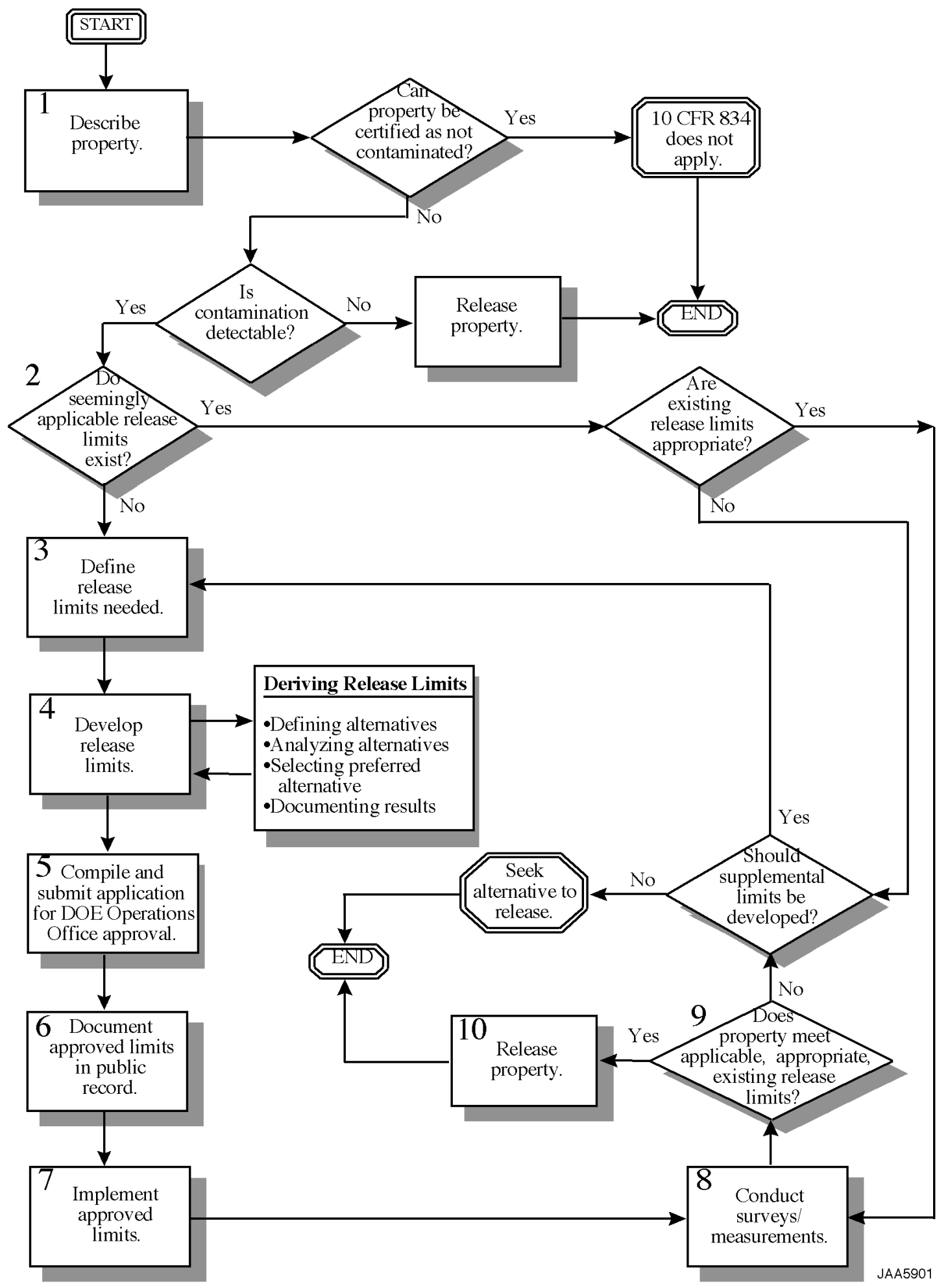

FIGURE 2.1 Authorized Release Process Flow Diagram (Source: DOE 1997) 
support the certification that non-real property is neither radioactive itself nor contaminated with radioactive materials. If a radiological history is available, it should be provided in Step 1, box $\mathbf{1 b}$ of the application. To assist users in reviewing the radiological history and developing a radiological certification, a written response to the following questions should be included in the application form:

- Has the concrete been exposed to unencapsulated or unconfined radioactive material during use or storage?

- Has the concrete been exposed to particle fields that could be expected to radiologically activate the concrete?

- Are radiological surveys available for the areas in which the concrete was used or stored?

- Are valid comparison data available for naturally occurring radionuclides in concrete that has not been used, stored, or exposed to transferable radioactive material?

These questions are repeated in Step 1, box 1 c of the application, and space has been provided for a response.

After the radiological history has been entered, a determination of whether the concrete contains residual radioactive material must be made, and Step 1, Section $\boldsymbol{d}$ of the application must be completed. This section of the application provides official determination that the concrete material either is or is not radiologically contaminated. If the concrete has been determined, through the radiological history, as not being radioactive and not containing residual radioactive material, then the concrete can be released. However, if the radiological history will not support determination that the concrete does not contain residual radioactive material, then the property must be treated as either (1) known to be contaminated or previously contaminated or (2) possibly contaminated. In either case, the rest of the release process must be followed. Concrete known to be either contaminated, previously contaminated, or possibly contaminated must be comprehensively surveyed before release to demonstrate compliance with release limits. The results of radiological surveys must be included in Step 1, box 1e.

If applicable release limits have not been previously approved, then commonly accepted survey protocols can be used to characterize the concrete material. This characterization information can be used to estimate dose and cost impacts and to help develop appropriate release limits. The survey protocols are described in Section 2.8. It should be recognized, however, that in these circumstances, it might be necessary to either resurvey or perform other radiological measurements on the concrete material after the release limits have been approved. 


\subsection{DETERMINE WHETHER APPLICABLE AUTHORIZED OR SUPPLEMENTAL LIMITS EXIST}

If the concrete material has been found to be either radioactive or possibly radioactive, an evaluation should be made of whether any existing release limits seem applicable to the concrete material proposed for release. A questionnaire has been provided in Step 2, box $2 \boldsymbol{a}$ to assist the user in determining whether applicable release limits exist. The answers to the questionnaire will lead the user along the most appropriate procedure path for the concrete material proposed for release. If existing authorized release limits apply and are appropriate, then the release process is continued at Step 8 (conduct surveys/measurements; the eighth step of the authorized release process), as discussed in Section 2.8. However, if release limits do not exist, are not applicable, or are inappropriate, new or amended limits must be developed.

If the concrete has been determined to be either contaminated, previously contaminated, or possibly contaminated, DOE requirements under Order 5400.5 and 10 CFR Part 834 allow the use of Surface Activity Guidelines (Table 2.1 and Step 2, box 2b) as authorized release limits for residual radioactive material on surfaces, but only after ALARA process requirements have been met. The ALARA process is an optimization process intended to identify one practicable alternative that would reduce radiation exposures to ALARA levels from among several alternatives that are reasonably expected to meet regulatory dose limits. In addition to considering dose, the process takes economic, environmental, technological, and public policy factors into account, with the goal of maximizing total benefits. Therefore, the activity levels given in Table 2.1 should not be treated as existing limits until ALARA process requirements have been fulfilled. Estimates showing that projected doses are low should be included in the application (Step 2, box 2c) supporting the use of the Surface Activity Guidelines as authorized release limits. This step is important when the authorized limits are developed as part of a process for releasing surface-contaminated concrete materials on a regular basis over a long operational period. If the surface activity levels are below those reported in Table 2.1 and Step 2, box $2 \boldsymbol{b}$ and if the estimated dose is below $1 \mathrm{mrem}$, then the user can proceed to the eighth step of the authorized release process (see Section 2.8).

Authorized release limits previously derived for similar concrete materials may also be used as authorized release limits for the concrete now proposed for release, provided the isotopic inventories are the same. The document number containing the authorized release limits and the authorized release limits themselves would be reported in Step 2, box $2 \boldsymbol{d}$. The concrete materials could be released if the measured concentrations are at or below the previously derived authorized release limits for all radionuclides present. If additional isotopes are present or the radionuclide concentrations reported in Step 1, box $1 e$ are greater than the concentrations listed in Step 2, box $2 d$, then either supplemental release limits or a new series of authorized release limits must be derived. Supplemental release limits are developed when existing authorized release limits are not applicable. Generally, however, every reasonable effort must be made to minimize the use of supplemental limits, which may be more or less restrictive than existing authorized limits. If previously derived authorized release limits are applicable, then these values should be reported in Step 2, box $2 \boldsymbol{d}$. If supplemental release limits must be derived, then the user must proceed to Step 3. 


\section{TABLE 2.1 Surface Activity Guidelines - Allowable Total Residual Surface Activity $\left(\mathrm{dpm} / \mathbf{1 0 0} \mathrm{cm}^{2}\right)^{\mathrm{a}}$}

$$
\text { Radionuclides }{ }^{b}
$$

Group 1 - Transuranics, I-125, I-129, Ac-227, Ra-226,

Ra-228, Th-228, Th-230, Pa-231

Group 2 - Th-natural, Sr-90, I-26, I-131, I-133, Ra-223, Ra-224, U-232, Th-232

Group 3 - U-natural, U-235, U-238, and associated decay products, alpha emitters

Group 4 - Beta-gamma emitters (radionuclides with decay modes other than alpha emission or spontaneous fission) except Sr-90 and others noted aboveg

\author{
Average $e^{c, d}$
}

100

300

1,000

3,000

200

5,000

15,000

1,000

5,000

15,000

1,000
$\mathrm{N} / \mathrm{A}^{\mathrm{i}}$

N/A

a As used in this table, dpm (disintegrations per minute) means the rate of emission by radioactive material as determined by counts per minute measured by an appropriate detector corrected for background, efficiency, and geometric factors associated with the instrumentation.

b Where surface contamination by both alpha- and beta-gamma-emitting radionuclides exists, the limits established for alpha- and beta-gamma-emitting radionuclides should apply independently.

c Measurements of average contamination should not be averaged over an area of more than $1 \mathrm{~m}^{2}$.

d The average and maximum dose rates associated with surface contamination resulting from beta-gamma emitters should not exceed $0.2 \mathrm{mrad} / \mathrm{h}$ and $1.0 \mathrm{mrad} / \mathrm{h}$, respectively, at $1 \mathrm{~cm}$.

e The maximum contamination level applies to an area of not more than $100 \mathrm{~cm}^{2}$.

f The amount of removable material per $100 \mathrm{~cm}^{2}$ of surface area should be determined by wiping an area of that size with dry filter or soft absorbent paper, applying moderate pressure, and measuring the amount of radioactive material on the wipe with an appropriate instrument of known efficiency. When removable contamination on objects with a surface area of less than $100 \mathrm{~cm}^{2}$ is determined, the activity per unit area should be based on the actual area, and the entire surface should be wiped. It is not necessary to use wiping techniques to measure removable contamination levels if direct scan surveys indicate that the total residual surface contamination levels are within the limits for removable contamination.

g This category of radionuclides includes mixed fission products, including the Sr-90 present in them. It does not apply to Sr-90 that has been separated from the other fission products or mixtures where the Sr-90 has been enriched.

h Property recently exposed or decontaminated should have measurement (smears) at regular time intervals to ensure that there is not a buildup of contamination over time. Because tritium typically penetrates material it contacts, the surface guidelines in Group 4 are not applicable to tritium. The Department has reviewed the analysis conducted by the DOE Tritium Surface Contamination Limits Committee ("Recommended Tritium Surface Contamination Release Guides," Feb. 1991) and has assessed potential doses associated with the release of property containing residual tritium. The Department recommends the use of the stated guideline as an interim value for removable tritium. Measurements demonstrating compliance of the removable fraction of tritium on surfaces with this guideline are acceptable to ensure that nonremovable fractions and residual tritium in mass will not cause exposures that exceed DOE dose limits and constraints.

i N/A - not applicable.

Source: Modified from "Response and to Questions and Clarification of Requirements and Processes" DOE 5400.5, Section II.5 and Chapter IV Implementation (Requirements Relating to Residual Radioactive Material), DOE Assistant Secretary for Environment Policy and Assistance (EH-41), Nov. 17, 1995. 


\subsection{DEFINE AUTHORIZED OR SUPPLEMENTAL LIMITS AS NEEDED}

Authorized or supplemental release limits must be derived if release limits for the concrete materials proposed for release do not exist or are not appropriate. The specification of such limits may vary depending on (1) the physical and radiological characteristics of the concrete materials proposed for release, (2) whether the release will be a one-time occurrence or a routine process occurring over time, and (3) whether restrictions will be placed on the concrete materials proposed for release. The authorized release limit applicability should be selected in Step 3, box 3a.

When use of surface release limits is appropriate, the authorized limits should be developed for both fixed and removable contamination for the known radionuclides. In addition, the survey/measurement protocols should be referenced in demonstrating compliance with the proposed release limits. These survey protocols should be included as an attachment to the authorized release application. In cases when surveying procedures are not possible, it may be possible to fashion release limits not involving residual surface concentration values if the doses reported in the ALARA section are found to be less than $1 \mathrm{mrem} / \mathrm{yr}$ to a maximally exposed individual (MEI).

The concrete material proposed for release may be able to be categorized to a specific group of materials (i.e., floors, basins pads, etc.). If this is the case, it may be beneficial to generate authorized release limits that can be applied to the specific group of materials.

\subsection{DEVELOP AUTHORIZED OR SUPPLEMENTAL LIMITS (ALARA ANALYSIS)}

DOE Order 5400.5 and 10 CFR Part 834 require that an ALARA process be used if release limits must be developed. The ALARA process is an optimization process intended to identify one alternative that would reduce radiation exposures to levels that are as low as practicable from among several alternatives that are reasonably expected to meet regulatory dose limits. The process also takes economic, environmental, technological, and public policy factors into account, with the goal of maximizing total benefits. The ALARA analysis for the authorized release of concrete materials considers a range of disposition alternatives, including the following:

A. Decontaminate the concrete material, dispose of all low-level radioactive waste (LLW), and crush and reuse the decontaminated material as roadbed material.

B. Crush the concrete material without decontamination and reuse it as roadbed material. 
C. Decontaminate the concrete material, dispose of all LLW, demolish the structure or material, and dispose of the decontaminated material as construction debris (placement in a nonradiological landfill) or reuse it as backfill.

D. Demolish the concrete material and either dispose (without decontamination) of it as construction debris (nonradiological landfill) or reuse it as backfill

E. Demolish (without decontamination) the concrete material and dispose of all materials as LLW.

F. Decontaminate the structure (valid for building only) and reuse.

G. Demolish the concrete material (with or without decontamination) or structure and entomb the demolished material.

Although a number of other alternatives could be considered, those listed above represent a wide range of disposition alternatives. A series of secondary alternatives that consider different types of decontamination methods, disposal locations, or other minor deviations from the base alternatives can be easily constructed by using the framework provided. The user should check all applicable alternatives in Step 4, box $4 \boldsymbol{a}$ that are going to be considered for the ALARA analysis. If different subalternatives are being considered, these should be identified in Step 4, box $4 \boldsymbol{b}$. The user should then proceed to the appropriate alternative(s) to continue the development of the authorized release limits. To account for possible subalternatives, the applicable sections of the application forms in Appendix A should be copied and filled in for each subalternative. As an example, if the user were to select Alternative A and Alternative B, then the user would complete all forms referring to Alternative A, then complete all forms referring to Alternative $\mathrm{B}$. This process would continue until all alternatives were analyzed. If the user selects two subalternatives (e.g., A1 and A2), then the user would complete two sets of Alternative A forms, one set for Alternative A1 and one for Alternative A2.

\subsubsection{Alternative A: Decontaminate, Crush, and Reuse}

The decontaminate, crush, and reuse alternative involves surface decontamination of the concrete material, disposal of the waste generated during decontamination at a LLW disposal facility, and crushing and reusing the decontaminated concrete. Any waste generated during the decontamination or crushing process is packaged and transported to an appropriate disposal facility. If the concrete material is volumetrically contaminated, surface removal techniques may not provide adequate decontamination. Hence, this alternative only applies to surfacecontaminated concrete materials. 
For surface-contaminated material, different decontamination techniques can be analyzed by comparing different subalternatives, or multiple decontamination techniques can be analyzed in a single alternative (e.g., 50\% decontaminated by using chelation, 50\% decontaminated by using mechanical scabbling). The wastes generated during decontamination activities are packaged and transported to an LLW facility. Radiological impacts associated with the transportation of the waste are estimated for persons living along the transportation corridor. Radiological impacts to the decontamination worker are not analyzed in this protocol since it is assumed the worker is already part of an ALARA program. However, the dose to the decontamination worker is considered in other documentation, such as the Characterization and Decision Analysis Report or the site ALARA analysis. Once decontaminated, the concrete is crushed to allow reuse. The reuse scenario considers use of the crushed concrete as aggregate for fresh concrete or asphalt. The radiological impacts to a construction worker associated with reuse of the concrete as roadbed material are analyzed in this alternative.

Appendix B lists the decontamination methods that are available for analysis and provides unit operational costs, production rates, and information on waste generation for each method. If site-specific data are available for the decontamination costs and decontamination factors, then those values should be used instead of the methodology provided in Section 3.3.1. The decontamination techniques considered, waste generation volumes, and estimated operational costs associated with each decontamination method should be reported in Step 4, box $\boldsymbol{A}_{-} \boldsymbol{a}$ in the application (Appendix A). The costs associated with demolition, crushing the concrete, performing project management duties, and carrying out other tasks are also provided in Chapter 3 (Section 3.3.2). These values should be reported in Step 4, box $\boldsymbol{A}_{-} \boldsymbol{b}$.

The transportation costs and radiological doses associated with Alternative A result from the transportation of waste generated during decontamination activities, as well as the transportation of other wastes during crushing and sorting. Appendix $\mathrm{C}$ provides unit-cost and unit-dose factors so that the costs and radiological doses from transportation activities can be factored into the ALARA analysis. The methodology for estimating the costs and radiological doses are provided in Section 3.3.3. However, if site-specific data are available, then those data should be used in place of the generic information provided in Appendix C. The origin, destination, number of shipments, distance to the final disposal destination, and costs should be entered into Step 4, box $\boldsymbol{A}_{-}$c. Similarly, the radiological impacts associated with the transportation of the waste from decommissioning, as well as with the processing wastes, should be entered in Step 4, box $\boldsymbol{A}_{-} \boldsymbol{d}$. The total cost and total dose from all transportation operations associated with Alternative A should be summed and reported in Step 4, boxes $\boldsymbol{A}_{-} \boldsymbol{c}$ and $\boldsymbol{A}_{-} \boldsymbol{d}$, respectively.

The impacts associated with reuse should be estimated from the unit-dose factors provided in Appendix D by using the methodology described in Section 3.3.4. The reuse scenario considers the dose to a construction worker from the reuse of the crushed concrete as roadbed material. The exposure pathways considered include external radiation, inhalation of contaminated dust, inhalation of radon (if applicable), and incidental ingestion of the crushed concrete. The radiological impacts from each isotope and each scenario should be reported in Step 4, box $\boldsymbol{A}_{-} \boldsymbol{e}$. After completing the application for Alternative A, the user would repeat this 
process for the next appropriate alternative. If this was the last alternative analyzed, the user should proceed to Step 4, box $4 \boldsymbol{c}$ (see Section 2.4.8).

\subsubsection{Alternative B: Crush and Reuse without Decontamination}

The evaluation procedure for this alternative provides estimates of the costs and radiological doses associated with direct reuse of the concrete without decontaminating it. Only the crushing and sorting operations would generate any waste. These wastes (rebar and fines generated during crushing operations) would be packaged and transported to an appropriate disposal facility. Unit cost factors are provided in Appendix C. If site-specific data are available for transportation costs, that information should be used instead of the unit costs provided in Appendix C. Because the concrete is not decontaminated before reuse, no costs are estimated for decontamination activities for this alternative. The user would complete Alternative B in the same manner as described above for Alternative A. After completing the appropriate sections for Alternative B, the user would proceed to the next appropriate alternative. If this was the last alternative analyzed, the user should proceed to Step 4, box 4c (see Section 2.4.8).

\subsubsection{Alternative C: Decontaminate, Demolish, and Dispose at Nonradiological Landfill or Reuse as Backfill}

Alternative $\mathrm{C}$ involves costs and radiological doses associated with decontamination, demolition, and disposing of the concrete material at a nonradiological landfill or using the crushed concrete as fill material. The waste generated during decontamination activities is to be packaged and transported to a LLW disposal facility. In general, the concrete material or structure is demolished after decontamination and then loaded onto a dump truck and transported to a nonradiological landfill. However, if a landfill requires the material to be packaged prior to disposal, the costs associated with packaging the material should be estimated. Radiological doses are estimated for persons living along the transportation routes for the shipments of both the waste and the demolished concrete material. Radiological doses are also estimated for persons working at the nonradiological disposal facility (see Section 3.3.5) since their activities are not part of a radiation protection program. An estimate of the radiation dose to a future resident living at the site after landfill closure is also provided. Radiological impacts to the decontamination worker are not analyzed in this protocol since it is assumed the worker is already part of an ALARA program. However, the dose to the decontamination worker is considered in other documentation, such as the Characterization and Decision Analysis Report or the site ALARA analysis.

As with Alternative A, Alternative $\mathrm{C}$ can have multiple subalternatives if multiple decontamination methods and/or multiple disposal sites are compared. If the material is to be used for backfill material, only the costs associated with decontamination, demolition, and crushing would be estimated. Since the operations of a worker backfilling a large opening would 
be similar to those of a landfill worker, the radiological impacts associated with backfilling by using the crushed concrete would be estimated by using the dose factors for a landfill worker. However, if the on-site workers are part of a radiation protection program, the doses to the on-site workers involved in backfill operations would not be estimated by using this protocol. The dose to a future resident living in a house constructed on top of the backfill would be estimated in the same manner as that used for the landfill scenario because it is assumed that the site would be released for unrestricted use.

The decontamination, operational, and transportation steps in Step 4, boxes $C_{-} \boldsymbol{a}$ through box $\boldsymbol{C}_{-} \boldsymbol{d}$ are completed in the same manner as described in Section 2.4.1. The only difference is that the costs for demolition include only the costs associated with segmenting the concrete material for transport. Packaging costs and shipping container costs (if applicable) are reported separately from the "Other Costs" in this alternative because they may constitute a major component of the total cost. The unit costs associated with packaging, transport, and disposal are

provided in Appendix C. If site-specific cost information is available, that information can be substituted for the estimated costs on the basis of data provided in Appendices B and C.

The radiological impacts associated with the disposal of the concrete material should be reported in Step 4, box $\boldsymbol{C}_{-} \boldsymbol{e}$. The dose from each radionuclide should be reported, and the total should reflect the sum of the doses from individual radionuclides. Previous assessments (Arnish et al. 1997, 2000) have shown that the MEI involved in the disposal of radioactive materials is either the driver of the truck transporting the material (if applicable) or the landfill worker. The dose to the landfill worker is proportional to the number of incoming shipments and the radionuclide concentration of the waste. The dose to the driver is a function not only of these parameters but also of the distance to the disposal facility. The exposure pathway considered for the driver only includes external radiation. However, the exposure pathways considered for the landfill worker include both external radiation and inhalation. Appendices $\mathrm{C}$ and $\mathrm{D}$ provide the unit-dose factors for the driver and the landfill worker, respectively.

The estimated dose to a future resident after landfill closure should be reported in Step 4, box $\boldsymbol{C}_{-} \boldsymbol{f}$. The dose for the resident is estimated in a manner similar to that used for the construction worker. However, the exposure pathways that are considered for the resident include not only external radiation, inhalation, and incidental ingestion, but also ingestion of plant foods, meat, milk, and seafood products. The unit-dose factors for the future resident scenario are provided in Appendix D. After completing Step 4, box $\boldsymbol{C}_{-} \boldsymbol{f}$, the user should proceed to the next alternative. If this was the last alternative analyzed, the user should proceed to Step 4, box $4 c$ (see Section 2.4.8).

\subsubsection{Alternative D: Demolish and Dispose at Nonradiological Landfill (without Decontamination) or Reuse as Backfill}

Alternative D involves the costs and radiological impacts associated with demolishing the concrete material and transporting it to a nonradiological landfill for disposal or using the 
crushed concrete as fill material. This alternative is similar to Alternative $\mathrm{C}$ except the concrete material is not decontaminated before demolition and crushing (if applicable). Radiological impacts must be estimated for the driver and landfill worker because this alternative assumes that the workers are not part of a radiation protection program. However, if these workers are part of a radiation protection program, the radiological impacts to these workers do not need to be estimated. The dose to a future resident after landfill closure is also estimated for this alternative. The unit-dose and unit-cost factors for transportation are provided in Appendix C; the unit-dose factors for the landfill worker and future resident are provided in Appendix E. The sections for this alternative are completed in the same manner as that used for Alternative $\mathrm{C}$. Multiple subalternatives can be investigated to compare the costs and radiological doses associated with disposal at different nonradiological landfills or with using the crushed concrete as backfill material. After completing Step 4, box $\boldsymbol{D}_{-} \boldsymbol{e}$, the user should proceed to the next alternative. If this was the last alternative analyzed, the user should proceed to Step 4, box $4 \boldsymbol{c}$ (see Section 2.4.8).

\subsubsection{Alternative E: Demolish and Dispose at a Low-Level Waste Facility (without Decontamination)}

Alternative $\mathrm{E}$ involves the costs and radiological impacts associated with demolition, packaging, transportation, and disposal of the concrete material at an LLW facility. This alternative assumes that the truck driver is part of a radiation protection program; therefore, the dose to the truck driver is not estimated. However, if the truck driver is not part of an ALARA program, the dose associated with transporting the concrete materials should be estimated and included in Step 4, box $\boldsymbol{E}_{-} \boldsymbol{c}$. The collective dose estimated for this alternative is the dose to persons living along the transportation corridor. The unit-dose factors for transportation are provided in Appendix C. For this alternative, the concrete material is not decontaminated before demolition. Since the workers at the LLW facility are in a radiation protection and ALARA program, the doses associated with the disposal operations are not estimated. In addition, the dose to a future resident is not estimated because administrative controls would be maintained at the LLW facility to prevent such exposure. The unit-cost factors for disposal are provide in Appendix B. However, site-specific cost information should be used instead if available. As for other alternatives, multiple subalternatives can be created by considering transportation to and disposal at multiple LLW facilities. After completing Step 4, box $\boldsymbol{E}_{-} \boldsymbol{d}$, the user should proceed to the next alternative. If this was the last alternative analyzed, the user should proceed to Step 4, box $4 c$ (see Section 2.4.8).

\subsubsection{Alternative F: Decontaminate and Reuse Building}

Alternative $\mathrm{F}$ involves the decontamination of the concrete structure, disposal of the waste generated during decontamination at a LLW disposal facility, and reuse of the decontaminated building as an office. An office building scenario was selected because of its conservatism as an exposure scenario. This scenario assumes that the building will be occupied 
daily for a total of 2,000 hours per year. This approach prevents the need for administrative controls on the building use.

If the concrete material is volumetrically contaminated, surface removal techniques may not provide adequate decontamination. Different decontamination techniques can be analyzed by comparing different subalternatives, or multiple decontamination techniques can be analyzed in a single alternative (e.g., 50\% decontaminated by using chelation and 50\% decontaminated by using mechanical scabbing). The wastes generated during decontamination activities are packaged and transported to an LLW facility. Radiological impacts associated with the transportation of the waste are estimated for persons living along the transportation corridor. For conservatism, it is assumed that once the building is decontaminated, it is released for industrial use. The radiological impacts to a person who spends 2,000 hours per year inside the building are analyzed in this alternative. If the time spent inside the building is different than 2,000 hours, the dose estimate can be adjusted accordingly. Radiological impacts to the decontamination worker are not analyzed in this protocol because it is assumed that the worker is already part of an ALARA program. However, the dose to the decontamination worker is considered in other documentation, such as the Characterization and Decision Analysis Report or the site ALARA analysis.

Appendix B lists the decontamination methods that are available for analysis and provides unit operational costs, production rates, and information on waste generation for each. If site-specific data are available for the decontamination costs and decontamination factors, those values should be used instead of the values provided in Appendix B or the values derived from the methodology provided in Section 3.3.1. The decontamination techniques considered, estimated waste to be generated, and estimated operational costs to be incurred for each decontamination method should be reported in Step 4, box $\boldsymbol{F}_{-} \boldsymbol{a}$.

The costs and radiological doses associated with transportation under Alternative F result from the transportation of waste generated during decontamination activities. Appendix C provides unit-cost and unit-dose factors to help estimate the costs and radiological doses associated with transportation activities. If available, site-specific data should be used rather than the information provided in Appendix C. The origin, destination, number of shipments, and costs should be entered into Step 4, box $\boldsymbol{F}_{-} \boldsymbol{b}$. The total dose from all transportation operations associated with Alternative F should be reported in Step 4, box $\boldsymbol{F}_{-} \boldsymbol{c}$.

The impacts associated with building reuse should be estimated with the unit-dose factors provided in Appendix D. The reuse scenario evaluates the dose to an office worker from occupying the decontaminated structure. The exposure pathways considered include external radiation, inhalation, incidental ingestion of the removable concrete, external exposure from deposited particles, inhalation of indoor radon aerosol, and external exposure during submersion in airborne radioactive dust. The radiological impacts from each isotope and each scenario should be reported in Step 4, box $\boldsymbol{F}_{-} \boldsymbol{d}$. After completing Alternative F, the user should proceed to the next appropriate alternative. If this was the last alternative analyzed, the user should proceed to Step 4, box $4 \boldsymbol{c}$ (see Section 2.4.8). 


\subsubsection{Alternative G: Entomb}

Alternative $\mathrm{G}$ evaluates the estimated costs and radiological impacts associated with demolishing the concrete structure or material and entombing it. For this alternative, decontamination may or may not be required. The site is released, and a person is assumed to build a house on top of the entombed material. The dose to the future resident is estimated in the same manner as that used for nonradiological landfills. If some form of radiological control is maintained at the site, it is not necessary to calculate radiological impacts associated with this alternative.

The estimated cost for the entombment should be reported in Step 4, box $\boldsymbol{G}_{\mathbf{B}} \boldsymbol{a}$, and the dose to a future resident after entombment of the material should be reported in Step $\overline{4}, \boldsymbol{b o x} \boldsymbol{G}_{-} \boldsymbol{b}$. The unit-dose factors for the future resident scenario are provided in Appendix D. After completing Step 4, box $\boldsymbol{G}_{-} \boldsymbol{b}$, the user should summarize results from the individual alternatives sections.

\subsubsection{Summary of Results from the Alternatives}

A summary section is provided in Step 4 , box $4 \boldsymbol{c}$ for the alternatives analyzed. This section summarizes the costs and radiological doses associated with the alternatives analyzed. This summary will permit quick comparison of the alternatives. The user will derive the authorized release limits on the basis of the results of the ALARA analysis as summarized in Step 4, box $4 c$.

\subsubsection{Proposed Authorized Release Limits}

The proposed authorized release limits are to be given in terms of concentration (either $\mathrm{pCi} / \mathrm{g}$ or disintigrations per minute $[\mathrm{dpm}] / 100 \mathrm{~cm}^{2}$ ) for the radionuclide profile listed in Step 1, box 1e. The method used to estimate the radiological doses on which the proposed authorized release limits are based is presented in Chapter 3. The proposed authorized release limits for each isotope should be presented in Step 4, box 4d. These limits are derived on the basis of the results of the ALARA analyses that were summarized in Step 4, box 4c. The proposed authorized release limits are derived by selecting the alternative that minimizes the dose to members of the public while, at the same time, minimizes the total cost. Hence, the proposed authorized release limits are not only a function of the radionuclide profile and concentration but also the scenario to which they apply. For example, the authorized release could be $\mathrm{x} \mathrm{pCi/g}$ for isotope $\mathrm{Y}$, provided the material is decontaminated to a certain level prior to release. The restriction on release (if any) would be reported in Step 5, box $5 \boldsymbol{a}$ of the application. Authorized release limits that would result in a dose greater than $1 \mathrm{mrem} / \mathrm{yr}$ to a member of the public are allowed only with approval of the DOE Office of the Assistant Secretary for Environment, Safety and Health 
(EH). For values less than $1 \mathrm{mrem} / \mathrm{yr}$, DOE Field Offices can approve the authorized release limits (for more detailed information, see Section 2.5).

\subsection{COMPILE AND SUBMIT APPLICATION FOR DOE OPERATIONS OFFICE APPROVAL}

The application for approval of authorized or supplemental limits must be submitted to the DOE Operations Office that has direct responsibility for oversight of the activity proposing the release.

While application, implementation, and approval of authorized limits for non-real property subject to surface contamination (consistent with guidelines described below) are the responsibility of DOE field and program elements, DOE Order 5400.5 requires EH-1 approval of authorized limits for residual radioactive material in mass or volume. However, authorized limits and survey protocols for residual radioactive material in mass or volume or surface contamination limits in lieu of Table 2.1 may be derived and approved by DOE Field Office managers without EH-1 approval if the following conditions are met:

1. On the basis of a realistic but reasonably conservative assessment of potential doses, it is demonstrated to the satisfaction of the responsible Field Office manager that -

a. The release of the concrete material will not cause a maximum individual dose to a member of the public in excess of 1 mrem in a year or a collective dose of more than 10 person-rem in a year;

b. A procedure is in place to maintain records of releases consistent with DOE Order 5400.5 requirements, and the survey or measurement results are reported are consistent with the data reporting guideline in the DOE November 1992 survey guidance and DOE/EH-173T; and

2. A copy of the authorized limits; measurements and survey protocols and procedures; supporting documentation, including a statement that the ALARA process requirements have been achieved; and appropriate material documenting any necessary coordination with states or NRC are provided to the Office of Environment (EH-4) at least 40 working days before the authorized limits become effective. In this case, EH-4 will

a. Provide written notification to the Field Office of the receipt of the material and 
b. Notify the Field Office, within 20 days of receipt, if the authorized limits or supporting materials are not acceptable; otherwise the authorized limits (including any conditions or limitations set forth by the approving DOE field elements) may be considered approved without written EH-1 approval.

Any limitations or restrictions on use of the concrete material (such as a requirement that the material be decontaminated to a certain level) should be entered at Step 5, box 5a. Similarly, any comments or recommendations by other federal or state agencies should be documented at Step 5, box $5 \boldsymbol{b}$. A copy of the appropriate survey protocols should be included in Step 5, box 5c. The user should review the application and submit the completed application form to the appropriate DOE Field Office. The steps to be taken once the authorized limits have been approved are discussed below.

\subsection{DOCUMENT APPROVED LIMITS IN THE PUBLIC RECORD}

Approved release limits must be made part of the public record. As a matter of policy, DOE recognizes that public participation must be a fundamental component of the Department's program operation, planning activities, and decision making. As a result, each DOE site is responsible for developing its own public participation program and plans in consultation with stakeholders and with the concurrence of appropriate DOE Headquarters program offices. As part of their plans, many sites may already have established public information repositories and/or public reading rooms. Almost all DOE sites already have designated public liaisons. Details on the specific process for documenting the approved release limits in the public record are available from the appropriate DOE Field Office

Once the authorized limits have been approved and documented in the public record, the approved limits can be implemented (Section 2.7).

\subsection{IMPLEMENT APPROVED LIMITS}

Implementation of release limits may require development of new site-specific procedures or modifications of existing site-specific procedures. In any event, it is the responsibility of either DOE or the contractor to identify any necessary procedural changes and to follow the existing site-specific administrative process for making and activating such changes before releasing the concrete materials. 


\subsection{CONDUCT SURVEYS/MEASUREMENTS}

The appropriate survey protocols must be followed either to verify that surface and internal residual radioactive material concentrations do not exceed applicable release limits or to determine whether radioactivity can be detected on or within the possibly contaminated concrete materials. Previously conducted surveys/measurements can be used when sufficient documentation exists to meet DOE Order 5400.5 and 10 CFR Part 834 requirements. To show the absence of detectable radioactivity and compliance with release limits, the documentation should show that surveys were completed in accordance with existing site-specific procedures and should include survey results.

\subsection{VERIFY THAT CONCRETE MATERIAL MEETS RELEASE LIMITS}

The documented results of the survey/measurements should be compared with the approved release limits to verify that the concrete materials proposed for release meet those limits. The results of this determination must be documented. Concrete materials that have been demonstrated to meet applicable, appropriate, existing authorized or supplemental release limits can be released for reuse, provided that all other release requirements have been met (see Section 2.10). Concrete materials shown to contain no detectable radioactivity can be released for any purpose after the survey results have been documented.

If applicable, existing authorized release limits are not met, an evaluation should be made to determine whether new or amended supplemental limits should be developed (see Section 2.2). Supplemental release limits are developed when existing authorized release limits are not applicable. Generally, however, every reasonable effort must be made to minimize the use of supplemental limits, which may be more or less restrictive than existing authorized limits. If supplemental limits need to be derived, the basis for the decision should be documented, and Step 3 (Section 2.3) should be revisited to begin the process for developing the new or amended supplemental limits. If it is decided that supplemental limits should not be developed, concrete materials that do not meet existing limits cannot be released for reuse. In such circumstances, an alternative management approach (e.g., sending the concrete material to an LLW disposal facility) would be necessary.

\subsection{RELEASE CONCRETE}

DOE Order 5400.5 and 10 CFR Part 834 prohibit the release of DOE non-real property (in this case, the concrete material) unless the following actions have been undertaken to protect the public and environment:

1. The concrete material has been appropriately surveyed/measured to identify and characterize its radiological condition; 
2. Residual radioactive material on concrete material surfaces or interior has been determined to meet acceptable release limits;

3. Required documentation has been completed; and

4. The owner or recipient of the released concrete material has been appropriately notified of the radiological status of the property and the availability of required documentation.

Before releasing concrete material for reuse, the responsible DOE or contractor personnel must verify that these conditions have been met. Additionally, the responsible personnel must ensure compliance with other applicable laws, regulations, and policies that may not be covered in these protocols. When compliance has been verified and documented, the concrete material may be released. 


\section{ALARA METHODOLOGY}

Section 3 describes the methodology used to estimate the costs and risks for each alternative in the ALARA analysis. Each of the alternatives presented in Section 2 consists of one or more of the following individual modules:

- Decontamination,

- Demolition/crushing,

- Packaging/transportation,

- Reuse, and

- Disposal/entombment.

Table 3.1 provides a list of the alternatives and the modules that are required to estimate the costs and associated radiological doses.

The costs or radiological doses (when applicable) can be estimated by using unit-cost or unit-dose factors. Radiological doses are estimated only for nonradiological workers (i.e., workers not already part of a radiation protection program). For the cost components, if site- or process-specific costs are available, then those values should be used instead of the unitcost factors presented in this document. The equations used to estimate the costs and radiological doses can be inserted into a spreadsheet program for easier implementation.

\subsection{UNIT-COST FACTORS}

The unit-cost factors are used to estimate the costs associated with each alternative to support the ALARA analysis. The costs are separated into different modules. The unit-cost factors were obtained from such sources as Ayers et al. (1999), Chen et al. (1996), Dickerson et al. (1995), and others. The unit-cost factors for the applicable modules are provided in this section as well as Appendices B through E.

\subsection{UNIT-DOSE FACTORS}

Unit-dose factors are used to estimate the radiological doses to members of the public from the reuse or disposal of concrete materials. These factors were generated with a suite of 


\section{TABLE 3.1 Comparison of Concrete Disposition Alternatives and the Corresponding Cost and} Dose Assessment Modules

\begin{tabular}{ll}
\hline \multicolumn{1}{c}{ Alternative } & \multicolumn{1}{c}{ Modules } \\
\hline $\begin{array}{l}\text { Decontaminate the concrete material, dispose of all low- } \\
\text { level waste (LLW), and crush and reuse the } \\
\text { decontaminated material }\end{array}$ & $\begin{array}{l}\text { Decontamination, Demolition/Crushing, Packaging/ } \\
\text { Transportation, and Reuse }\end{array}$ \\
$\begin{array}{l}\text { Crush and reuse the concrete without decontamination } \\
\text { Demolition/Crushing, Packaging/Transportation, and } \\
\text { Reuse }\end{array}$ \\
$\begin{array}{l}\text { Decontaminate the concrete, dispose of all LLW, } \\
\text { demolish the structure, and dispose of the } \\
\text { decontaminated material as construction debris } \\
\text { (nonradiological landfill) or reuse as backfill } \\
\begin{array}{l}\text { Demolish the structure and dispose of the concrete } \\
\text { material as construction debris or reuse as backfill } \\
\text { (nonradiologicial landfill }- \text { no decontamination) }\end{array} \\
\begin{array}{l}\text { Demolish the structure and dispose of all materials as } \\
\text { LLW }\end{array}\end{array} \quad \begin{array}{l}\text { Peckaging/Transportation, and Disposal } \\
\text { Disposal }\end{array}$ \\
$\begin{array}{l}\text { Decontaminate the building and reuse as office space } \\
\text { Demolition/Crushing, and Packaging/Transportation }\end{array}$ \\
$\begin{array}{l}\text { Demolish the building and entomb on-site } \\
\text { Decontamination, Packaging/Transportation, and }\end{array}$ \\
\hline
\end{tabular}

computer codes such as RESRAD ( $\mathrm{Yu}$ et al. 1993), RESRAD-BUILD ( $\mathrm{Yu}$ et al. 1994), RESRAD-RECYCLE (Cheng et al. 1999), TSD-DOSE (Pfingston et al. 1998), and RISKIND (Yuan et al. 1995), as appropriate. The unit-dose factors are presented in Appendices B through $\mathrm{E}$ and discussed for the specific modules in the sections below.

\subsection{MODULES}

The analysis of the alternatives presented in Section 2 is the key component of the ALARA analysis. Many of the alternatives share key operations (such as decontamination or demolition). The alternatives can, therefore, be subdivided in to a series of individual modules, as specified at the beginning of Section 3. The following subsections describe the methodologies used to estimate the costs and radiological doses associated with the five modules that make up the different alternatives. 


\subsubsection{Decontamination}

Decontamination is assumed to be performed by workers who are part of a radiation protection program; therefore, the associated doses are already kept at ALARA levels and are not included in the dose estimates calculated to establish authorized release. However, this dose must be considered in other documentation, such as the Characterization and Decision Analysis Report or the site ALARA analysis. For surface-contaminated concrete materials, decontamination can reduce the total activity of the material. The techniques used to remove contaminants that are on the surface only and not tightly adhered to the substrate are different than those used for contaminants that are "fixed" to the substrate. Fixed contaminants can be in surface layers or can have migrated into the concrete matrix. In general, contaminants are less likely to migrate into the concrete when the surface is painted or coated. In dry areas, contaminant migration into unpainted concrete will probably be limited to the top quarter inch. If the concrete has been exposed to contaminated liquids for long periods, the contaminants may migrate farther into the concrete matrix.

The process rates and costs for decontamination can vary greatly because of the large number of factors that affect technology efficiency and effectiveness. One commonly used technique for removing loose contamination is spraying the surface with a nontoxic cleaner and wiping, although strippable coatings have also been used with success. The use of water and abrasive blasting is limited because of problems with handling the waste that is generated. A common technique for removing fixed contamination from concrete walls and floors is the use of hand-held or automated scabbling units. These units mechanically remove a thin layer (1/8 to $1 / 4$ inch) from the surface of the concrete.

\subsubsection{Decontamination Efficiency}

Decontamination efficiency $\left(\mathrm{D}_{\mathrm{EF}}\right)$, a measure of the amount of contamination left after decontamination, must be estimated so that the dose from either reuse or disposal after decontamination can be estimated. The decontamination efficiency is assumed to be the inverse of the decontamination factor (DF) (i.e., $\mathrm{D}_{\mathrm{EF}}=1 / \mathrm{DF}$ ). The $\mathrm{D}_{\mathrm{EF}}$ value of 0 is interpreted as meaning all radioactive material has been removed from the surface of the concrete material; the $\mathrm{D}_{\mathrm{EF}}$ value of 1 means no decontamination was performed. Currently, decontamination is limited to surface-contaminated concrete materials; hence, for volumetrically contaminated concrete (through activation), the decontamination efficiency should be set equal to 1 .

If field measurements are available, the decontamination efficiency is derived in the following manner:

$$
D_{E F}=\frac{A_{\text {Final }}}{A_{\text {Initial }}},
$$


where

$$
\begin{aligned}
& A_{\text {Initial }}=\text { total activity }\left(\mathrm{dpm} / 100 \mathrm{~cm}^{2}\right) \text { prior to decontamination and } \\
& A_{\text {Final }}=\text { total activity }\left(\mathrm{dpm} / 100 \mathrm{~cm}^{2}\right) \text { after decontamination. }
\end{aligned}
$$

If no field measurements are available, the decontamination efficiency can be estimated for contamination distributed uniformly throughout a given thickness of the concrete material as:

$$
D_{E F}=\left[1-\left(\frac{R R}{T_{C}}\right) \times P\right],
$$

where

$$
\begin{aligned}
D_{E F} & =\text { decontamination efficiency applied to all isotopes, } \\
R R & =\text { removal rate (thickness/pass), } \\
P & =\text { number of passes or treatments, and } \\
T_{C} & =\text { thickness of the contamination. }
\end{aligned}
$$

Appendix B lists some decontamination technologies for both loose and fixed contamination and provides estimates of the parameter values for the removal rate.

\subsubsection{Waste Generation}

Decontamination activities generate waste, which must be disposed of at an approved disposal facility. The total amount of generated waste is used as input when estimating the cost associated with the transportation of the decontamination wastes to a LLW disposal facility. Depending on the extent of the contamination and the decontamination technologies selected, the volume of waste generated can range from low (as is the case with hand scrubbing) to quite high (as is the case with abrasive blasting). For decontamination technologies that provide a waste generation rate in units of cubic feet of waste generated per square foot of material treated $\left(\mathrm{ft}^{3} / \mathrm{ft}^{2}\right)$, the total amount of waste generated is estimated as:

$$
\text { WasteGen }=\text { Area } \times \text { WGR }+ \text { Other, }
$$


where

$$
\begin{aligned}
\text { WasteGen }= & \text { total amount of waste generated }\left(\mathrm{ft}^{3}\right) \\
\text { Area }= & \text { area of the concrete material being decontaminated }\left(\mathrm{ft}^{2}\right), \\
W G R= & \text { waste generation rate }\left(\mathrm{ft}^{3} / \mathrm{ft}^{2}\right), \text { and } \\
\text { Other }= & \begin{array}{l}
\text { other wastes generated during the decontamination process (personal } \\
\text { protective equipment }[\mathrm{PPE}], \text { chemicals, etc.) }
\end{array}
\end{aligned}
$$

For fixed contamination, decontamination is performed by physically removing layers of concrete. Hence the total amount of waste generated is estimated as:

$$
\text { WasteGen }=\text { Area } \times R R \times P+\text { Other },
$$

where

$$
\begin{aligned}
R R & =\text { removal rate (thickness } / \text { pass }), \text { and } \\
P & =\text { number of passes or treatments. }
\end{aligned}
$$

If a concrete structure is decontaminated with abrasive blasting, the total amount of waste generated is a combination of both factors and is therefore estimated as:

$$
\text { WasteGen }=\text { Area } \times[(R R \times P)+W G R]+\text { Other } .
$$

Appendix B provides the waste generation rates for some decontamination technologies.

\subsubsection{Decontamination Costs}

Three components must be considered in estimating the cost for the decontamination technologies: (1) amortization cost for the equipment, (2) process costs, and (3) labor costs. The amortization cost for the equipment takes into account the actual cost for purchasing the decontamination equipment, the equipment life, and the interest rate. The process cost is the cost of operating the equipment. This cost may include supplies required to run the equipment or may include costs for routine maintenance. The labor costs are the costs associated with workers using the decontamination equipment. Although other costs may also be associated with 
decontamination, only these costs are considered here because they would contribute the most to the total cost associated with decontamination activities. The hourly amortization cost, $E C$, over the life of the equipment is given as:

$$
E C=\left[\frac{P I(1+I)^{N}}{\left\{(1+I)^{N}-1\right\}}\right] \times \frac{1}{8760},
$$

where

$$
\begin{aligned}
P & =\text { purchase cost of the equipment, } \\
I & =\text { interest rate, } \\
N & =\text { equipment life }(\mathrm{yr}), \text { and } \\
1 / 8760 & =\text { conversion from per year to per hour. }
\end{aligned}
$$

The total cost for decontamination operations is estimated as;

$$
\text { Decon } \$=E C \times U T+A \times P \times\left(P C+\frac{1}{P R} \times H C\right)
$$

where

$$
\begin{aligned}
\text { Decon } \$ & =\text { total cost for decontamination }(\$), \\
E C & =\text { amortization cost for the decontamination equipment }(\$ / \mathrm{h}), \\
U T & =\text { equipment use time for decontamination operations }(\mathrm{h}), \\
A & =\text { area }\left(\mathrm{ft}^{2}\right), \\
P & =\text { number of passes or treatments, } \\
P C & =\text { process cost }\left(\$ / \mathrm{ft}^{2} / \text { pass or treatment }\right),
\end{aligned}
$$




$$
\begin{aligned}
& P R=\text { production rate }\left(\mathrm{ft}^{2} / \mathrm{h} / \text { pass or treatment }\right), \text { and } \\
& H C=\text { hourly cost for a decontamination worker }(\$ / \mathrm{h}) .
\end{aligned}
$$

The values for the capital cost, production rates, and hourly costs for some decontamination technologies are provided in Appendix B.

\subsubsection{Demolition/Crushing}

For all alternatives except building reuse, the concrete material would undergo some demolition and possibly further processing, including crushing. The methods used to demolish concrete structures include controlled blasting and use of wrecking balls, backhoe-mounted rams, rock splitters, paving breakers, and others. The size and type of concrete material to be demolished would determine the actual method selected. As they are for decontamination, the demolition workers are assumed to be part of a radiation protection program; hence, the radiological doses associated with demolition are already kept ALARA. The unit-cost factor for demolition has been estimated at $\$ 1 / \mathrm{ft}^{2}\left(\$ 10.76 / \mathrm{m}^{2}\right)$ of building area (Ayers et al. 1999). If sitespecific values are available then they should be used in place of the value provided above. The cost for demolition is therefore estimated as:

$$
\text { Demol } \$=A \times \text { DemolCF }
$$

where

$$
\begin{aligned}
\text { Demol\$ } & =\text { cost for demolition }(\$) \\
A & =\text { building area }\left(\mathrm{ft}^{2}\right), \text { and } \\
\text { DemolCF } & =\text { demolition unit cost factor }\left(\$ / \mathrm{ft}^{2}\right) .
\end{aligned}
$$

For the alternatives that involve further processing of the concrete material by crushing, the cost for crushing is estimated as:

$$
\text { Crush } \$=M \times C F
$$


where

$$
\begin{aligned}
\text { Crush } \$=\text { cost for crushing the concrete material }(\$), \\
M=\text { mass of the material (metric ton }[\mathrm{MT}] \text { ), and } \\
C F=\text { unit cost factor for crushing the material. }
\end{aligned}
$$

Ayers et al. (1999) provide a lognormal distribution for the cost associated with concrete crushing. On the basis of the parameters of the lognormal distribution, the $50^{\text {th }}$ percentile value for the unit-cost factor for crushing and screening the concrete material was estimated at $\$ 23 / \mathrm{MT}$. If site-specific information is available, then that value should be used instead of the number provided above.

The process of crushing concrete into aggregate for reuse generates unusable fines that must be sent to a disposal facility. The mass of fines generated has been estimated to be approximately $30 \%$ of the mass of the precrushed concrete (Ayers et al. 1999). However, if sitespecific information is available, that value should be used instead of the number provided above. Hence, the amount of fines $\left(M_{\text {Fines }}\right)$ is estimated as:

$$
M_{\text {Fines }}=F \times M \text {, }
$$

where

$$
\begin{aligned}
& F=\text { fraction of mass converted to fines and } \\
& M=\text { mass of the pre-crushed concrete. }
\end{aligned}
$$

\subsubsection{Packaging/Transportation}

The packaging/transportation module provides the means for estimating the costs and risks associated with packaging and transporting the concrete materials and any waste generated from decontamination, demolition, and crushing activities. The methodology for estimating the dose to a truck driver transporting these materials is applied to the alternatives involving transport of the concrete material to a nonradiological landfill. For such alternatives, the assumption is made that the truck driver is not a radiation worker and, hence, is not part of a radiation protection program. 


\subsubsection{Packaging/Transportation Costs}

Two components are involved in estimating the costs of transportation activities packaging costs and the costs associated with the transportation operations. The packaging costs are estimated by evaluating the expenses associated with the packaging of the concrete materials into 55-gal drums, B25-type containers, or soft-sided containers. The type of container selected for use would depend on the required need. For example, if the concrete material was demolished and sent to a disposal facility, it is more likely that the concrete would be placed into either a B25-type container or soft-sided container rather than into a 55-gal drum. However, waste generated during decontamination or fines generated during crushing would normally be placed in 55-gal drums.

For 55-gal drums, the number of containers can be estimated on the basis of the mass of the material by using the equation below:

$$
\text { Containers }=\frac{M}{\rho} \times \frac{1}{\text { Vol }_{\text {container }}} \text {, }
$$

where

$$
\begin{aligned}
M & =\text { mass of the material, } \\
\rho & =\text { bulk density, and } \\
V \text { Vl }_{\text {container }} & =\text { volume of the shipping container. }
\end{aligned}
$$

If the volume of the material (rather than the mass of the material) is provided, then the number of containers required can be estimated by using this equation:

$$
\text { Containers }=\frac{V}{V o l_{\text {container }}},
$$

where

$$
\begin{aligned}
V & =\text { volume of the material and } \\
V o l_{\text {container }} & =\text { volume of the cargo container (provided in Appendix C). }
\end{aligned}
$$


It should be noted that the B25 and soft-sided containers have weight restrictions that must be met. These restrictions are approximately 8,000 lb per container for B25 containers and $24,000 \mathrm{lb}$ for soft-sided containers. Therefore, if the amount of material placed into the cargo container is limited by weight, the number of containers can be estimated from:

$$
\text { Containers }=\frac{M}{K} \text {, }
$$

where

$$
\begin{aligned}
M & =\operatorname{mass}(\mathrm{lb}) \text { and } \\
K & =\text { weight restriction (lb). }
\end{aligned}
$$

If the volume of the material is known, then the number of containers can be estimated as

$$
\text { Containers }=\frac{V \times \rho}{K},
$$

where

$$
\begin{aligned}
& V=\text { volume }\left(\mathrm{ft}^{3}\right) \text {, and } \\
& \rho=\text { bulk density }\left(\mathrm{lb} / \mathrm{ft}^{3}\right) .
\end{aligned}
$$

For most applications, the bulk density for segmented concrete is approximately $112 \mathrm{lb} / \mathrm{ft}^{3}$ $\left(1.8 \mathrm{~g} / \mathrm{cm}^{3}\right)$.

The total costs for packaging either the concrete or waste materials can be estimated by using the following equation:

$$
\text { Packaging } \$=\sum_{\text {MaterialType }}[(U L C+C C) \times \text { Containers }] \text {, }
$$


where

$$
\begin{aligned}
\text { Packaging } \$ & =\text { packaging } \operatorname{cost}(\$), \\
U L C & =\text { unit loading costs }(\$ / \text { container }), \\
C C & =\text { container cost }(\$ / \text { container), and } \\
\text { Containers } & =\text { number of containers (estimated by using the previous equations). }
\end{aligned}
$$

The unit loading and container costs are provided in Appendix C.

The transportation costs are estimated by applying the methodology from Chen et al. (1996). The total transportation cost is proportional to the total number of shipments. The total number of shipments can be estimated from the number of containers that need to be shipped. For the B25-type containers, the assumption is that 5 containers are shipped per truck and 10 per railcar, while 2 soft-sided containers can be shipped per truck and 6 per railcar. For the 55-gal drums, up to 36 drums can be shipped per truck, while up to 120 may be shipped per railcar. The number of drums per truck or railcar is based on a bulk density of $180 \mathrm{lb} / \mathrm{ft}^{3}$, a gross vehicle weight restriction of 80,000 lb for trucks, and a 60-ton payload capacity per railcar (Chen et al. 1996). The per-shipment costs are estimated by using the following equation:

$$
\text { Trans } \$=(U C F \times D+S C F) \times \text { Shipments },
$$

where

$$
\begin{aligned}
\text { Trans } \$ & =\text { transportation cost }(\$), \\
U C F & =\text { unit-cost factor (\$/shipment-mi), } \\
D & =\text { distance to the disposal site (mi), } \\
S C F & =\text { per-shipment cost factor }(\$ / \text { shipment), and } \\
\text { Shipments } & =\text { number of shipments. }
\end{aligned}
$$

The unit-cost factors and the per-shipment cost factors are provided in Appendix C. 


\subsubsection{Transportation Dose - Driver Scenario}

For the alternatives that involve transportation of the demolished concrete materials to a nonradiological landfill, the dose to the driver of the truck transporting that material is evaluated. Since the material is assumed to be released from radiological control, it is further assumed that the truck driver is not a radiation worker and therefore is not part of a radiation protection program. Evaluation of the driver dose takes into consideration the dose associated with the operation of the vehicle, as well as routine stops for rest or fuel. Truck stops are assumed to occur at a rate of $0.011 \mathrm{~h} / \mathrm{km}$ (Neuhauser et al. 1992), and an average speed of $50 \mathrm{~km} / \mathrm{h}$ is maintained while moving. The only applicable exposure pathway considered is external radiation. The radiation dose to the driver is estimated as:

$$
D_{\text {Driver }}=\sum_{i=1}^{n} A_{i} \times U D F_{i} \times D_{E F} \times M \times D \times 1000
$$

where

$$
\begin{aligned}
D_{\text {Driver }} & =\text { driver dose }(\mathrm{mrem}), \\
A_{i} & =\text { initial activity concentration }(\mathrm{pCi} / \mathrm{g}) \text { of the } \mathrm{i}^{\text {th }} \text { radionuclide, } \\
U D F_{i} & =\text { unit-dose factor for the driver scenario }(\mathrm{mrem} / \mathrm{pCi} / \mathrm{km}), \\
D_{E F} & =\text { decontamination efficiency (concrete material only) (unitless), } \\
M & =\text { mass }(\mathrm{kg}), \\
D & =\text { distance to the disposal facility }(\mathrm{km}), \text { and } \\
1,000 & =\text { a conversion factor from } \mathrm{kg} \text { to } \mathrm{g} .
\end{aligned}
$$

For either concrete materials that have not undergone decontamination or for wastes generated during decontamination activities, the decontamination efficiency should be equal to 1 . The unitdose factors for the driver scenario were calculated with the TSD-DOSE computer model (Pfingston et al. 1998) and are provided in Appendix C. 


\subsubsection{Transportation Dose to Persons along the Transportation Corridor}

Persons living along (off-link) or sharing (on-link) the transportation corridor could be exposed to low levels of radiation during the shipment of concrete or waste materials. The collective dose to the off-link and on-link receptors is estimated by using unit-risk factors generated with the computer programs RISKIND (Yuan et al. 1995) and TSD-DOSE (Pfingston et al. 1998). The unit-dose factors for the off-link receptors were estimated by assuming that $90 \%$ of the travel occurred in a rural area (population density of 7 persons $/ \mathrm{km}^{2}$ ), $5 \%$ in a suburban area (766 persons $\left./ \mathrm{km}^{2}\right)$, and $5 \%$ in an urban area $\left(1,282\right.$ persons $\left./ \mathrm{km}^{2}\right)$ (U.S. Department of Commerce [DOC] 1993). The average speed of the truck while moving was assumed to be $50 \mathrm{~km} / \mathrm{h}$. The unit-dose factors for the on-link receptors were estimated on the basis of two persons per vehicle and a traffic density of 930 vehicles per hour (Yuan et al. 1995). The only applicable exposure pathway considered is external radiation. On the basis of these assumptions, the collective dose to off- and on-link persons can be estimated by using the following equation:

$$
D_{\text {On-link }, \text { Off-link }}=\sum_{i=1}^{n} A_{i} \times U D F_{i} \times D_{E F} \times D \times \text { Shipments }
$$

where

$$
\begin{aligned}
D_{\text {On-link,Off-link }} & =\text { on- and off-link collective dose (person-rem), } \\
A_{i} & =\text { initial activity ( } \mathrm{pCi}) \text { for the } \mathrm{i}^{\text {th }} \text { radionuclide, } \\
U D F_{i} & \left.=\text { unit-dose factor for the } \mathrm{i}^{\text {th }} \text { radionuclide (person-rem } / \mathrm{pCi} / \mathrm{km}\right), \\
D_{E F} & =\text { decontamination efficiency (concrete material only), } \\
D & =\text { distance to the disposal site }(\mathrm{km}), \text { and } \\
\text { Shipments } & =\text { number of shipments. }
\end{aligned}
$$

For either concrete that has not undergone decontamination or for wastes generated during decontamination activities, the decontamination efficiency should be equal to 1 . 


\subsubsection{Reuse}

The reuse module considers the dose to construction workers from the reuse of the concrete materials if the structure is demolished or to the office worker if the building is reused. Depending on the alternative, the concrete may or may not be decontaminated before reuse.

\subsubsection{Construction Worker Scenario}

The unit-dose factors for the construction worker scenario were estimated with the RESRAD-RECYCLE computer code (Cheng et al. 1999). Since the concrete material is free released, it is assumed that the exposed construction worker is not a radiation worker and is not included in a radiation protection program. The scenario was based on the assumption that a construction worker would take 0.067 hour to construct $1 \mathrm{yd}^{2}$ of road surface (Ayers et al. 1999). The exposure pathways assumed for this scenario include external exposure, ingestion, and inhalation of airborne particulates. The inhalation and ingestion pathways are included because dust would be generated from the concrete materials during construction activities. For external exposure, the source was modeled as a 100-MT full cylinder with a $15-\mathrm{cm}$ thickness, a radius of $940 \mathrm{~cm}$, and a density of $2.4 \mathrm{~g} / \mathrm{cm}^{3}$. The average distance from the source was assumed to be $1 \mathrm{~m}$. An inhalation rate of $1.2 \mathrm{~m}^{3} / \mathrm{h}$ was used in the calculations. The dust loading concentration was assumed to be $0.001 \mathrm{~g} / \mathrm{m}^{3}$, and the respirable fraction was set at 0.1 . An ingestion rate of $0.00625 \mathrm{~g} / \mathrm{h}$ was used for the construction worker. It was estimated that the construction worker would be required to work a total of 22.3 hours for a throughput of $100 \mathrm{MT}$ of concrete.

For the ALARA analysis, the dose to the construction worker was estimated in the following manner:

$$
D_{\text {Construction }}=\sum_{i=1}^{n} A_{i} \times U D F_{i} \times M \times D_{E F} \times(1-F),
$$

where

$$
\begin{aligned}
D_{\text {Construction }}= & \text { dose to the construction worker }(\mathrm{mrem}), \\
A_{i}= & \text { initial activity concentration }(\mathrm{pCi} / \mathrm{g}) \text { for the } \mathrm{i}^{\text {th }} \text { isotope, } \\
U D F_{i}= & \text { unit-dose factor for the } \mathrm{i}^{\text {th }} \text { radionuclide for the construction } \\
& \text { worker scenario }(\mathrm{mrem} / \mathrm{pCi} / \mathrm{g} / \mathrm{MT}), \\
M= & \text { mass of the crushed concrete material in metric tons }(\mathrm{MT}),
\end{aligned}
$$




$$
\begin{aligned}
D_{E F}= & \text { decontamination efficiency for the decontamination technique } \\
& \text { considered (unitless), and } \\
F= & \text { fraction of the material converted to "fines" from the demolition } \\
& \text { and crushing process (unitless). }
\end{aligned}
$$

For conservatism, $\mathrm{F}$ could be set to 0 , indicating that none of the concrete material is lost to fines. However, Ayers et al. (1999) assume that $30 \%(\mathrm{~F}=0.3)$ of the material is converted to fines. Appendix D provides the unit-dose factors for the construction worker scenario for the isotopes analyzed. For the alternatives that do not consider decontamination prior to reuse, $\mathrm{D}_{\mathrm{EF}}$ is set to 1 .

\subsubsection{Building Reuse Scenario}

The unit-dose factors for the building reuse scenario were calculated for a building occupant with the RESRAD-BUILD computer code (Yu et al. 1994). Because the building is released from radiological control, it is assumed the building occupant is not a radiation worker and is not part of a radiation protection program. The scenario was based on a building area of $200 \mathrm{~m}^{2}$ and a building height of $2.5 \mathrm{~m}$. The contamination was assumed to be present only on the floor. Occupancy would occur immediately after the building was released. The occupant would spend 2,000 hours per year inside the building. The exposure pathways included in this scenario are direct external exposure from surface sources, inhalation of resuspended surface contamination, inadvertent ingestion of surface contamination, inhalation of indoor radon aerosol, external exposure from deposited particles, and external exposure during submersion in airborne radioactive dust. For direct external exposure, the midpoint of the occupant was assumed to be at a height of $1 \mathrm{~m}$ from the center of the source. All other parameters were set at RESRAD-BUILD default values.

For the ALARA analysis, the dose to the building occupant in the building reuse scenario is estimated by the following equation:

$$
D_{\text {building reuse }}=\sum_{i=1}^{n} A_{i} \times U D F_{i} \times D_{E F} \text {, }
$$

where

$$
\begin{aligned}
& D_{\text {building reuse }}=\text { dose to the building resident }(\mathrm{mrem}) \\
& \qquad A_{i}=\text { the initial activity concentration }(\mathrm{pCi} / \mathrm{g}) \text { for the } \mathrm{i}^{\text {th }} \text { isotope, }
\end{aligned}
$$




$$
\begin{aligned}
U D F_{i}= & \text { unit-dose factor for the } \mathrm{i}^{\text {th }} \text { radionuclide for the building reuse } \\
& \text { scenario }(\mathrm{mrem} / \mathrm{pCi} / \mathrm{g}), \text { and } \\
D_{E F}= & \text { decontamination efficiency for the decontamination technique } \\
& \text { considered (unitless). }
\end{aligned}
$$

Appendix D provides the unit-dose factors for the building reuse scenario for the isotopes analyzed. For the alternatives that do not consider decontamination prior to building reuse, the $\mathrm{D}_{\mathrm{EF}}$ is set to 1 .

\subsubsection{Disposal/Entombment}

The disposal/entombment module evaluates the costs and radiological doses associated with either disposal or entombment of the concrete materials. For the alternatives that include disposal at a nonradiological landfill, the doses to the landfill worker and a future resident at the former landfill site must be estimated. However, for the alternative that considers entombment, only the dose to a future resident at the former building site is considered.

\subsubsection{Disposal Costs}

The disposal/entombment costs of the concrete materials can be estimated by using the following equation:

$$
\text { Disposal } \$=V \times U C F
$$

where

$$
\begin{aligned}
\text { Disposal } \$ & =\operatorname{cost}(\$), \\
V & =\text { volume of the concrete materials }\left(\mathrm{ft}^{3}\right), \text { and } \\
F & =\text { unit-cost factor for burial }\left(\$ / \mathrm{ft}^{3}\right) .
\end{aligned}
$$

The unit-cost factor for disposal at a LLW landfill has been estimated at $\$ 65 / \mathrm{ft}^{3}$ (Gresalfi et al. 1995). Unit-cost factors for disposal at nonradiological landfills vary by site; therefore sitespecific data should be used for the ALARA assessment. 


\subsubsection{Landfill Worker}

For the alternatives that involve the transportation of the demolished concrete material to a nonradiological landfill, the dose to the landfill worker is evaluated. Since the material is assumed to be released from radiological control, it is further assumed that the landfill worker is not a radiation worker and is not part of a radiation protection program. The exposure pathways include external exposure and inhalation. The inhalation pathway was included in this scenario because dust from the concrete materials may be generated when the concrete material is being placed in the landfill. The unit-dose factors for the landfill worker scenario were generated with the TSD-DOSE computer code (Pfingston et al. 1998). The dose to the landfill worker can be estimated by the following equation:

$$
D_{\text {Landfill Worker }}=\sum_{i=1}^{n} A_{i} \times U D F_{i} \times M \times D_{E F} \times 1000
$$

where

$$
\begin{aligned}
& D_{\text {Landfill Worker }}=\text { dose to the landfill worker (mrem), } \\
& \qquad \begin{aligned}
A_{i} & =\text { initial activity concentration of the concrete material }(\mathrm{pCi} / \mathrm{g}), \\
U D F & =\text { unit-dose factor for the landfill scenario }(\mathrm{mrem} / \mathrm{pCi}), \\
M & =\text { mass of the material }(\mathrm{kg}), \\
D_{E F} & =\text { decontamination efficiency (unitless), and } \\
1,000 & =\text { conversion factor from } \mathrm{kg} \text { to g. }
\end{aligned}
\end{aligned}
$$

For concrete material that has not been decontaminated, the decontamination efficiency is set to 1. Appendix E provides the unit-dose factors for the landfill worker scenario.

\subsubsection{Future Resident}

The dose to a future resident is calculated for the alternatives that consider the disposal of the concrete materials at a nonradiological disposal facility or by on-site entombment. The scenario involves a person that builds a house either on top of the former landfill or at the former site of the DOE structure some time after the landfill or DOE facility has closed. All exposure pathways are active and include external radiation, inhalation, and ingestion (crops, meat, milk 
and soil). The RESRAD computer code (Yu et al. 1993) was used to generate the unit-dose factors for the future resident scenario. The dose to the future resident can be estimated with the following equation:

$$
D_{\text {Future Resident }}=\sum_{i=1}^{n} A_{i} \times U D F_{i} \times M \times D_{E F},
$$

where

$$
\begin{aligned}
D_{\text {Future Resident }}= & \text { dose to the future resident }(\mathrm{mrem}), \\
A_{i}= & \text { initial activity concentration }(\mathrm{pCi} / \mathrm{g}) \text { of the } \mathrm{i}^{\text {th }} \text { radionuclide, } \\
U D F_{i}= & \text { unit-dose factor for the } \mathrm{i}^{\text {th }} \text { radionuclide for the future resident } \\
& (\mathrm{mrem} / \mathrm{yr} / \mathrm{pCi} / \mathrm{g} / \mathrm{MT}), \\
M= & \text { mass of the material (metric tons }[\mathrm{MT}]), \text { and } \\
D_{E F}= & \text { decontamination efficiency. }
\end{aligned}
$$

For the alternatives where the concrete material is not decontaminated before disposal, $\mathrm{D}_{\mathrm{EF}}$ is equal to 1. Appendix E provides the unit-dose factors to the future resident. 


\section{REFERENCES}

Arnish, J., et al., 1997, unpublished information, Argonne National Laboratory, Argonne, Ill., June.

Arnish, J., et al., 1999, P2Pro(RSM): A Computerized Management Tool for Implementing DOE's Authorized Release Process for Radioactive Scrap Metals, ANL/EAD/TM-85, Argonne National Laboratory, Argonne, Ill., May.

Arnish, J., et al., 2000, Development of Authorized Release Limits for the Animal/Chemical Pits and Glass Holes Project, Letter Report, Argonne National Laboratory, Argonne, Ill., Feb.

Ayers, K.W., et al., 1999, Reuse of Concrete from Contaminated Structures, Department of Civil and Environmental Engineering, Vanderbilt University, Nashville, Tenn., Jan.

Chen, S.-Y., et al., 1996, Assessment of Risks and Costs Associated with Transportation of U.S. Department of Energy Radioactively Contaminated Carbon Steel, ANL/EAD/TM-62, Argonne National Laboratory, Argonne, Ill., Sept.

Chen, S.-Y., et al., 1999, “Authorized Release of DOE's Non-Real Property: Process and Approach," The Radiation Safety Journal 77(2 suppl):S40-S48, Aug.

Cheng, J.-J., et al., 1999, unpublished information on RESRAD-RECYCLE, Argonne National Laboratory, Argonne, Ill, Jan.

Dickerson, K.S., et al., 1995, Demonstration Recommendations for Accelerated Testing of Concrete Decontamination Methods, ORNL/TM-13098, Oak Ridge National Laboratory, Oak Ridge, Tenn., Dec.

DOC - See U.S. Department of Commerce.

DOE - See U.S. Department of Energy.

Gresalfi, M., et al., 1995, "Cost of Low Level Waste Disposal-Baseline," U.S. Department of Energy presentation slides, Oak Ridge National Laboratory, Oak Ridge, Tenn.

Neuhauser, K.S., et al., 1992, RADTRAN 4 Volume II: Technical Manual, SAND89-2370, Sandia National Laboratories, Albuquerque, N.M., Feb. 
Pfingston, M., et al., 1998, TSD-DOSE: A Radiological Dose Assessment Model for Treatment, Storage, and Disposal Facilities, ANL/EAD/LD-4 (Rev.1), Argonne National Laboratory, Argonne, Ill., Sept.

U.S. Department of Commerce, 1993, 1990 Census of Population and Housing, Supplementary Reports, Urbanized Areas of the United States and Puerto Rico, 1990 CPH-S-1-2, Economics and Statistics Administration, Bureau of the Census, Washington, D.C., Dec.

U.S. Department of Energy, 1990, Order 5400.5, Radiation Protection of the Public and the Environment, as amended, Washington, D.C., Feb.

U.S. Department of Energy, 1997, Draft Handbook for Controlling Release for Reuse or Recycle of Property Containing Residual Radioactive Material, Interim Guide - for Interim Use and Comment, Washington, D.C., June.

Yu, C., et al., 1993, Manual for Implementing Residual Radioactive Material Guidelines Using RESRAD, Version 5.0, ANL/EAD/LD-2, Argonne National Laboratory, Argonne, Ill., Sept.

Yu, C., et al., 1994, RESRAD-BUILD: A Computer Model for Analyzing the Radiological Doses Resulting from the Remediation and Occupancy of Buildings Contaminated with Radioactive Material, ANL/EAD/LD-3, Argonne National Laboratory, Argonne, Ill., Nov.

Yuan, Y.C., et al., 1995, RISKIND - A Computer Program for Calculating Radiological Consequences and Health Risks from Transportation of Spent Nuclear Fuel, ANL/EAD-1, Argonne National Laboratory, Argonne, Ill., Nov. 
APPENDIX A:

AUTHORIZED RELEASE APPLICATION 
Application for the Development of Authorized Release Limits for Concrete 


\section{Authorized Release Process}

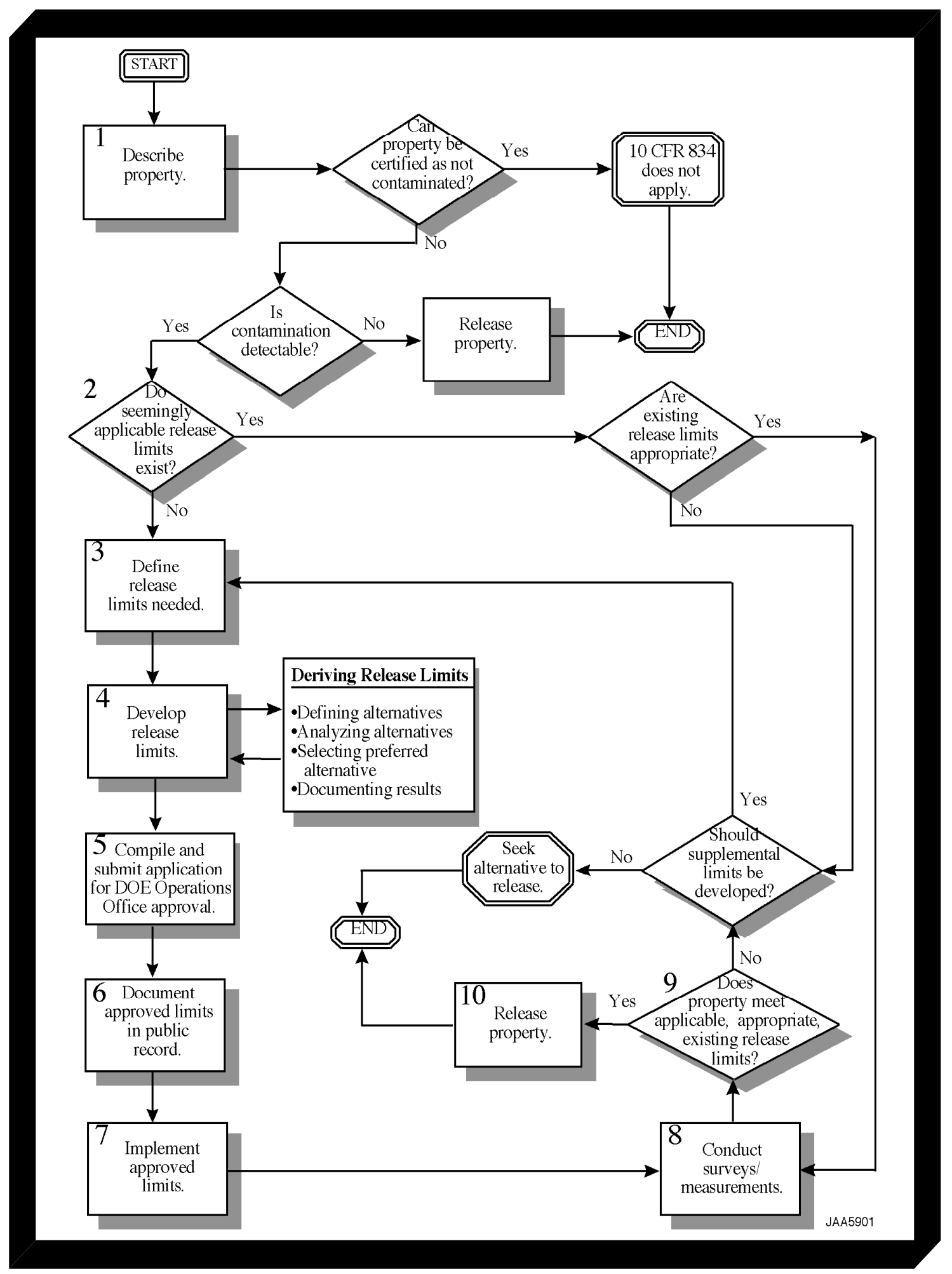




\section{Step 1. Characterize Property and Prepare a Description}

( Chapter 2, Section 2.1)

\section{(All information in the form should be typed)}

\section{1a Physical Characteristics}

Describe the physical characteristics of the concrete material (volume of material, age, location, etc.)

Volume: $\mathrm{m}^{3}$ metric tons

\section{1b Radiological History}

Describe the radiological history of the concrete material (i.e., known areas of contamination, etc.) 


\section{Step 1. Characterize Property and Prepare a Description} (Chapter 2, Section 2.1)

\section{1c Radiological History Questionnaire}

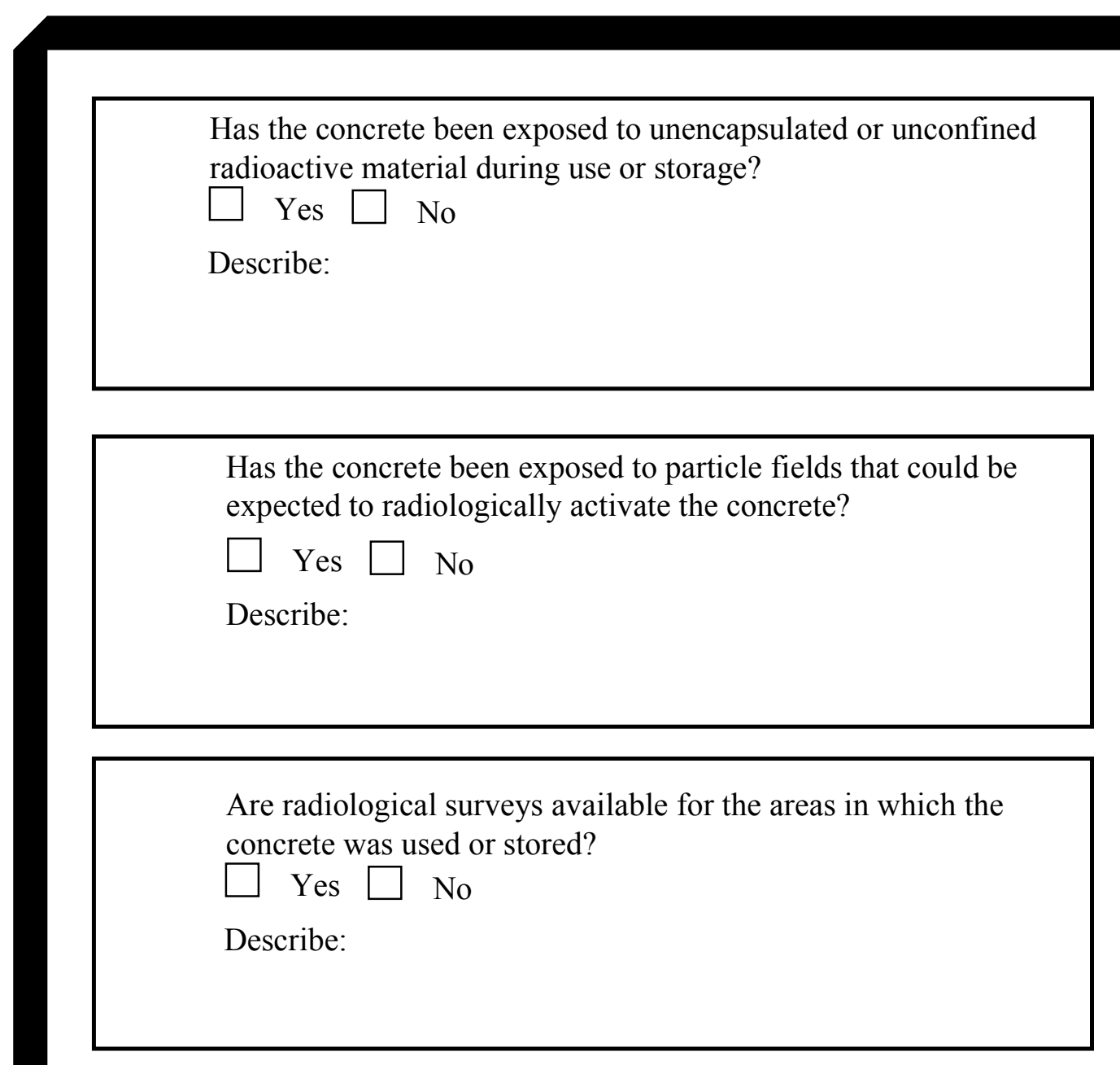

Are valid comparison data available for naturally occurring radionuclides in concrete that HAS NOT been used, stored, or exposed to transferable radioactive material?

$\square$ Yes $\square$ No

Describe: 


\section{Step 1. Characterize Property and Prepare a Description} (Chapter 2, Section 2.1)

\section{1d Radiological Determination}

Based on the answers provided in questions $1 \mathrm{~b}, 1 \mathrm{c}$, and $1 \mathrm{~d}$, the concrete being released is determined to be radioactive, non radioactive (circle one).

Basis for non radioactive

Radiological history, process knowledge, and release surveys indicate Contamination is unlikely (answered "no"to all questions in 1c)

Signed:

Date:

(Radiological Control Representative)

Signed:

Date:

(Facility Manager)

Check one box:

$\square \quad$ The material has been determined to be non radioactive.

DOE Order 5400.5 and 10 CFR 834 do not apply. Release material.

$\square \quad$ The material is considered to be as radioactive.

Go to Step 1, box e. 


\section{Step 1. Characterize Property and Prepare a Description}

(Chapter 2, Section 2.1)

1e Results of the Radiological Survey

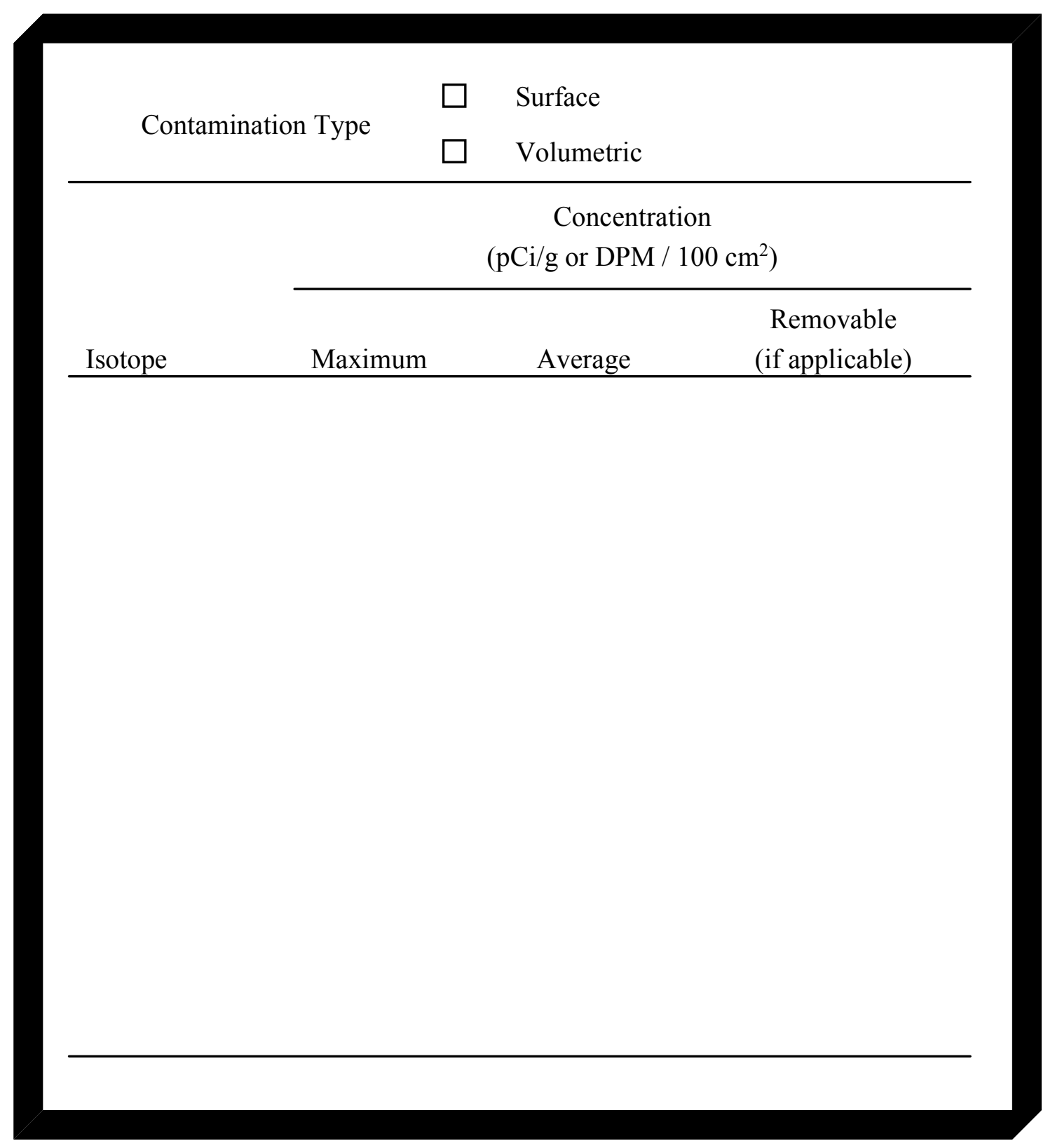

Go to Next Page 
Step 2. Determine Whether Applicable Authorized or

Supplemental Limits Exist (Chapter 2, Section 2.2)

2a Check for existing release limits

Check one box:

$\square \quad$ Concrete material is contaminated only on the external surfaces.

Go to Step 2, box $2 b$.

Concrete material is contaminated throughout the volume of the material, and authorized release limits have not been derived for a similar concrete material. Go to Step 3, box 3a

Concrete material is contaminated throughout the volume of the material and authorized release limits have been derived for other concrete materials.

Go to Step 2, box 2d 


\section{Step 2. Determine Whether Applicable Authorized or Supplemental Limits Exist (Chapter 2, Section 2.2)}

\section{2b Surface Activity Guidelines}

\begin{tabular}{|c|c|c|c|}
\hline \multicolumn{4}{|c|}{ A llowable Total Residual Surface Activity $(\mathrm{dpm} / 100 \mathrm{sq}-\mathrm{cm})^{1}$} \\
\hline R A D IO N U C LIDE S ${ }^{2}$ & A V E R A G E ${ }^{3 / 4}$ & M A X IM U M ${ }^{4 / 5}$ & REM OVAB LE ${ }^{2}$ \\
\hline $\begin{array}{l}\text { Group } 1-\text { Transurancics, I-125, I-129, Ac-227, Ra-226, Ra- } \\
228 \text {. Th }-228 \text {, Th }-230 \text {, Pa-231 }\end{array}$ & 100 & 300 & 20 \\
\hline $\begin{array}{l}\text { Group } 2-\text { Th-natural, S r-90, I26, I-131, I-133, Ra-223, Ra- } \\
224, \\
\text { U-232, Th-232 }\end{array}$ & 1000 & 3000 & 200 \\
\hline $\begin{array}{l}\text { Group } 3 \text { - U-natural, U-235, U-238, and associated decay } \\
\text { products, alphaemitters }\end{array}$ & 5000 & 15000 & 1000 \\
\hline $\begin{array}{l}\text { Group } 4 \text { - Beta-gamma em itters (radionuclides with decay } \\
\text { modes other than alpha emission or spontaneous fission) } \\
\text { exceptSr-90 and others noted above? }\end{array}$ & 5000 & 15000 & 1000 \\
\hline Tritium (applicable to surface and subsurface) ${ }^{8}$ & $\mathrm{~N} / \mathrm{A}$ & $\mathrm{N} / \mathrm{A}$ & 10000 \\
\hline
\end{tabular}

*Excerpt from Response to Questions and to Questions and Clarification of Requirements and Processes: DOE 5400.5 , Section II.5 and Chapter IV Implementation (Requirements Relating to Residual Radioactive material),
DOE Assistant Secretary for EnvironmentPolicy and Assistance (EH-41), Nov, 17, 1995 . NOTES

'As used in this table, dpm (disintegrations per minute) means the rate of emission by radioactive
material as determined by counts perminute measured by an appropriatedetector for background, efficiency and geometric factors associated with the instrumentation.

${ }^{2}$ Where surface contamination by both alpha-and beta-gamma-emitting radionuclides exists, the limits
established foralpha-and beta-gamma-emitting radionuclides should apply independently.

${ }^{3}$ Measurements of average contamination should not be averaged overan area of more than $1 \mathrm{sq}-\mathrm{m}$.

${ }^{4}$ The average and maximum dose rates associated with surface contamination resulting from beta-gam $m$ a emitters should not exceed $0.2 \mathrm{mrad} / \mathrm{h}$, and $1.0 \mathrm{mrad} / \mathrm{h}$, respectively, at $1 \mathrm{~cm}$

${ }^{5}$ The maximum contamination level applies to an area of not more than $100 \mathrm{sq}-\mathrm{cm}$ ${ }^{6}$ The amount of removable material per 100 sq-cm of surface area should be determined by wiping an
area of that size with dry filter or softabsorbent paper, applying moderate pressure, and measuring the amount of
radioactive material on the wipe with an appropriate instrument of knownefficiency. When removable radioactive material on the wipe with an appropriate instrument of known efficiency. When removable
contamination on objects of surface area less than 100 sq-em is determined. The activity per unit area should be based on the actual area and the entire surface should be wiped. It is not necessary to use wiping techniques to measure removable contamination levels if direct scan surve
levels are within the limits for removable contamination.

This category of radionuclides includes mixed fission products, including the SR-90 present in them. It does not appl
enriched.

${ }^{8}$ Property recently exposed or decontaminated should have measurement (smears) at regular time intervals to ensure that there is not a build-up of contamination over time. Because tritium typically penetrates analysis conducted by the DOE Tritium Surface contamination Lim its Committee ("Recommended Tritium Surface Contam ination Release Guides," Feb. 1991), and has assessed potential doses associated with the release of property containing residual tritium. The department recommends the use of the state guideline as an interim value for this guideline are Measurements demonstrating complance of the removable fraction of tritium on surfaces with this guideline are acceptable to ensure that nonremovable fractions and residual tritium in mass will not cause
exposures that exceed DOE dose limits and constraints.

NOTE: DOE requirements under Order 5400.5 and 10 CFR 834 allow the use of Surface Activity Guidelines (above table) as authorized release limits for residual radioactive material on surfaces only after ALARA process requirements have been met. Therefore the activity levels given in the Surface Activity Guidelines table should not be treated as existing limits until ALARA process requirements have been fulfilled. Dose estimates showing that projected doses are low should be included in documentation supporting the Surface Activity Guidelines. This may be important when the authorized limits are developed as part of a process for releasing surface contaminated concrete materials on a regular basis over a long operational period 


\section{Step 2. Determine Whether Applicable Authorized or Supplemental limits Exist (Chapter 2, Section 2.2)}

2c-1 Are the Surface Activity Guidelines Appropriate?

Document Number

Estimated Dose Based on the Surface Activity Guidelines

\begin{tabular}{llll}
\hline & & Measured & \\
Isotope & Dose $/\left(\mathrm{dpm} / 100 \mathrm{~cm}^{2}\right)$ & Concentration & Dose \\
{$\left[\mathrm{mrem} /\left(\mathrm{dpm} / 100 \mathrm{~cm}^{2}\right)\right]$} & $\left(\mathrm{dpm} / 100 \mathrm{~cm}^{2}\right)$ & $(\mathrm{mrem})$ \\
\hline
\end{tabular}

Line 2c-1 Total (Sum doses from all isotopes) 
Step 2. Determine Whether applicable Authorized or Supplemental Limits Exist (Chapter 2, Section 2.2)

2c-2 Are the Surface Activity Guidelines appropriate?

Write Total (Line 2c.1) from the previous page mrem

Check one box:

Line $2 \mathrm{c}-2$ is less than or equal to $1 \mathrm{mrem}$ and the concentrations provided in $\mathbf{1 e}$ are less than those provided in $\mathbf{2 b}$.

See Chaper 2, Sections 2.8, 2.9, and 2.10

Line $2 \mathrm{c}-2$ is greater than 1 mrem or an ALARA analysis has not been previously conducted.

Go to Step 3, box 3a 
Step 2. Determine Whether Applicable Authorized or Supplemental Limits Exist (Chapter 2, Section 2.2)

2d Previously Derived Authorized or Supplemental Release Limits (If none exist go to Step 3)

Document Number

Enter the authorized release limit for each isotope

Concentration ( $\mathrm{pCi} / \mathrm{g}$ ) 
Step 2. Determine Whether Applicable Authorized or

Supplemental Limits Exist (Chapter 2, Section 2.2)

2e Are the existing authorized release limits appropriate?

Check one box:

The concentrations of the isotopes reported in 1e are less than or equal to the authorized release limits reported in $\mathbf{2 d}$.

See Chapter 2, Sections 2.8, 2.9, and 2.10

The concentrations of the isotopes reported in $\mathbf{1 e}$ are greater than the

$\square \quad$ authorized release limits reported in $\mathbf{2 d}$; or there are isotopes listed in 1e that are not included in $\mathbf{2 d}$.

Go to Next Page 
Step 3. Define Release Limits Needed (Chapter 2, Section 2.3)

3a Release limit applicability

Release limits will be based on (check all that apply)

$\square$ Surface Contamination (DPM $/ 100 \mathrm{~cm}^{2}$ )

$\square \quad$ Volumetric Contamination ( $\mathrm{pCi} / \mathrm{g}$ )

$\square$ One-time release

$\square \quad$ Routine release 


\section{Step 4. Develop Release Limits (Chapter 2, Section 2.4)}

\section{4a Primary ALARA Alternatives}

Check alternatives considered for ALARA analysis

A. Decontaminate the concrete material, dispose of all lowlevel waste (LLW), and crush and reuse the decontaminated material

B. Crush and reuse the concrete without decontamination

C. Decontaminate the concrete, dispose of all LLW, demolish the structure and dispose of the decontaminated material as construction debris (nonradiological landfill) or reuse as backfill

D. Demolish the structure and dispose of the concrete material as construction debris (nonradiological landfill - no decontamination) or reuse as backfill

E. Demolish the structure and dispose of all materials as LLW

F. Decontaminate the building and reuse as office space

G. Demolish the building and entomb on-site

\section{4b Secondary ALARA Alternatives}

Indicate the number of the primary alternative then the letter of the secondary alternative considered (i.e. A1, A2, etc.) 


\section{Step 4. Develop Release Limits (Chapter 2 Section 2.4.1)}

\section{Alternative A}

Decontaminate the concrete material, dispose of all low-level waste (LLW), and crush and reuse the decontaminated material

$\mathrm{A}_{-} \mathrm{a}$

Decontamination Method(s)

\begin{tabular}{cccc}
\hline $\begin{array}{c}\text { Decontamination } \\
\text { Method }\end{array}$ & $\begin{array}{c}\text { Decontamination } \\
\text { Factor }\end{array}$ & $\begin{array}{c}\text { Waste Generation } \\
\left(\mathrm{ft}^{3}\right)\end{array}$ & $\begin{array}{c}\text { Cost } \\
(\$)\end{array}$ \\
\hline
\end{tabular}

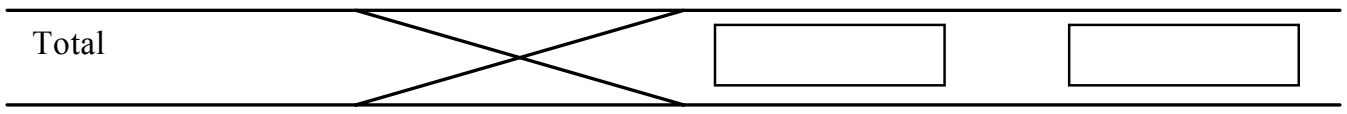

A_b

Operational Costs

\begin{tabular}{lc}
\hline $\begin{array}{c}\text { Operation } \\
\text { Cost } \\
(\$)\end{array}$ \\
\hline Crush Concrete \\
Management Costs \\
\hline Tother Costs \\
\hline
\end{tabular}




\section{Step 4. Develop Release Limits (Chapter 2, Section 2.4.1)}

\section{Alternative A (Cont.)}

Decontaminate the concrete material, dispose of all low-level waste (LLW), and crush and reuse the decontaminated material

$\mathrm{A}_{-} \mathrm{c}$

Transportation Costs

\begin{tabular}{|c|c|c|c|c|}
\hline Origin & Destination & \# of Shipments & $\begin{array}{c}\text { Distance } \\
(\mathrm{km})\end{array}$ & $\begin{array}{c}\text { Cost } \\
(\$)\end{array}$ \\
\hline
\end{tabular}

Total

\section{A_d}

Transportation Impacts

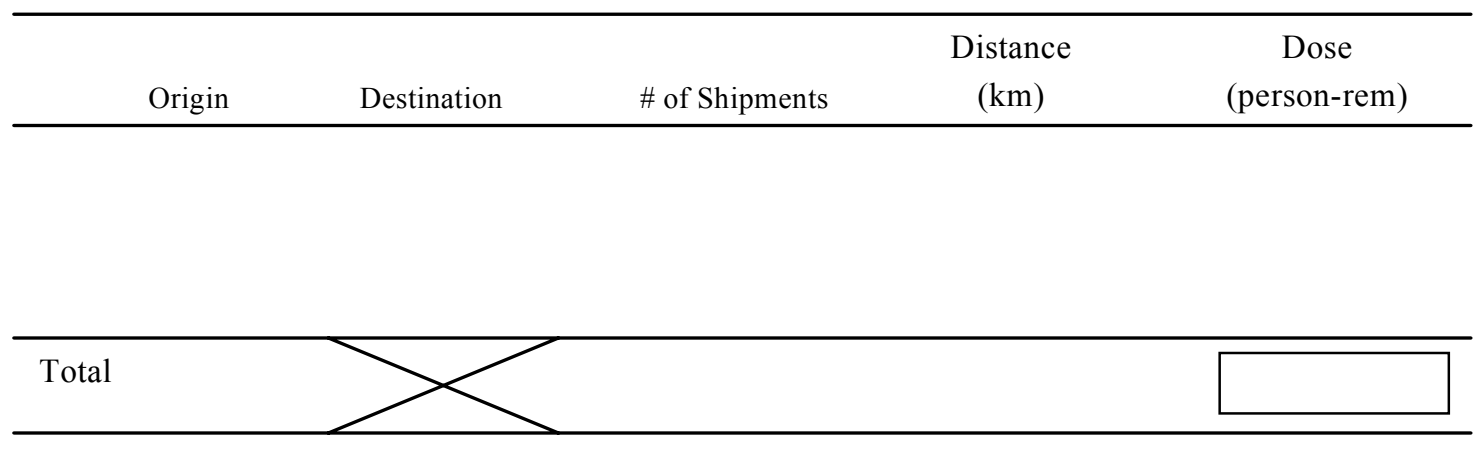




\section{Step 4. Develop Release Limits (Chapter 2, Section 2.4.1)}

\section{Alternative A (Cont.)}

Decontaminate the concrete material, dispose of all low-level waste (LLW), and crush and reuse the decontaminated material

A_e

Concrete Reuse-Impacts

\begin{tabular}{|c|c|c|c|c|}
\hline \multirow[b]{2}{*}{ Isotope } & \multicolumn{2}{|c|}{$\begin{array}{c}\text { Concentration } \\
\left(\mathrm{pCi} / \mathrm{g} \text { or } \mathrm{DPM} / 100 \mathrm{~cm}^{2}\right)\end{array}$} & \multicolumn{2}{|c|}{ Dose (mrem) } \\
\hline & Average & Maximum & Average & Maximum \\
\hline
\end{tabular}

$\square \longdiv { \square }$

Stop [If last alternative proceed to Step 4, box 4c. If want to analyze another alternative See Chapter 2, Section 2.4] 


\section{Step 4. Develop Release Limits (Chapter 2, Section 2.4.2)}

\section{Alternative B}

Crush and reuse the concrete without decontamination

B1

Operational Costs

\begin{tabular}{lc}
\hline \multicolumn{1}{c}{ Operation } & \multicolumn{1}{c}{ Cost } \\
$(\$)$
\end{tabular}

B2

Transportation Costs

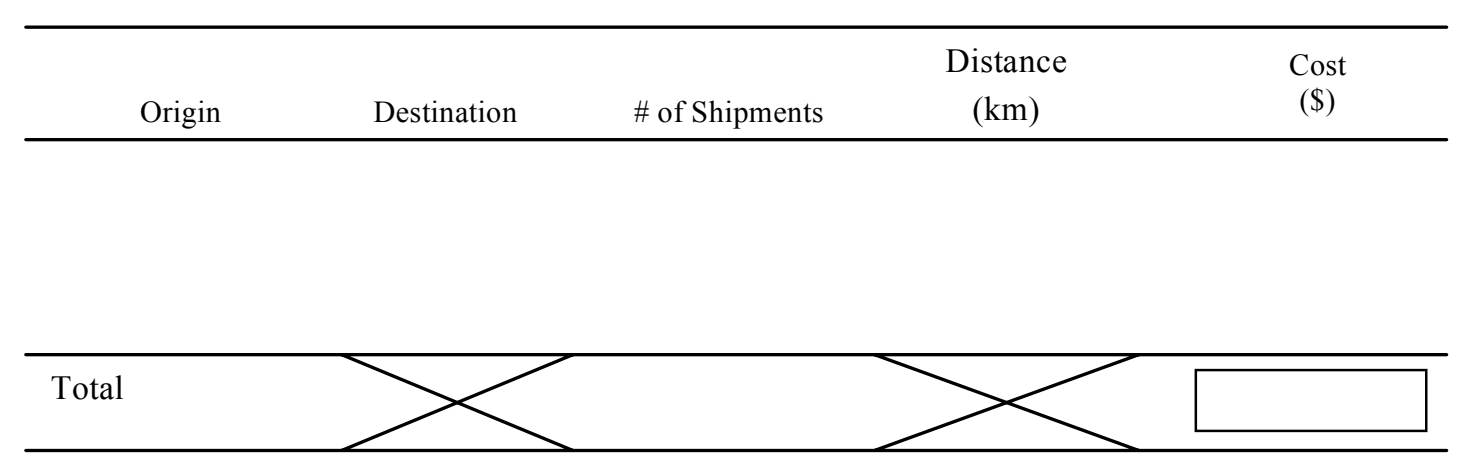




\section{Step 4. Develop Release Limits (Chapter 2, Section 2.4.2)}

\section{Alternative B (Cont.)}

Crush and reuse the concrete without decontamination

B3

Transportation Impacts

\begin{tabular}{lcccc}
\hline Origin & Destination & \# of Shipments & $\begin{array}{c}\text { Distance } \\
(\mathrm{km})\end{array}$ & $\begin{array}{c}\text { Dose } \\
\text { (person-rem) }\end{array}$ \\
\hline & & & \\
\hline Total & & & \\
\hline
\end{tabular}




\section{Step 4. Develop Release Limits (Chapter 2, Section 2.4.2)}

\section{Alternative B (Cont.)}

Crush and reuse the concrete without decontamination

B4

Concrete Reuse-Impacts

\begin{tabular}{|c|c|c|}
\hline & $\begin{array}{c}\text { Concentration } \\
\left(\mathrm{pCi} / \mathrm{g} \text { or } \mathrm{DPM} / 100 \mathrm{~cm}^{2}\right)\end{array}$ & Dose (mrem) \\
\hline Isotope & Maximum & Maximum \\
\hline
\end{tabular}

Stop [If last alternative proceed to Step 4, box 4c. If want to analyze another alternative See Chapter 2, Section 2.4] 


\section{Step 4. Develop Release Limits (Chapter 2, Section 2.4.3)}

\section{Alternative C}

Decontaminate the concrete material, dispose of all low-level waste (LLW), demolish the structure, and dispose the concrete material at a nonradiological landfill or reuse as backfill material

$\mathrm{C}_{-} \mathrm{a}$

\section{Decontamination Method(s)}

\begin{tabular}{cccc}
\hline $\begin{array}{c}\text { Decontamination } \\
\text { Method }\end{array}$ & $\begin{array}{c}\text { Decontamination } \\
\text { Factor }\end{array}$ & $\begin{array}{c}\text { Waste Generation } \\
\left(\mathrm{ft}^{3}\right)\end{array}$ & $\begin{array}{c}\text { Cost } \\
(\$)\end{array}$ \\
\hline
\end{tabular}

Total

C_b

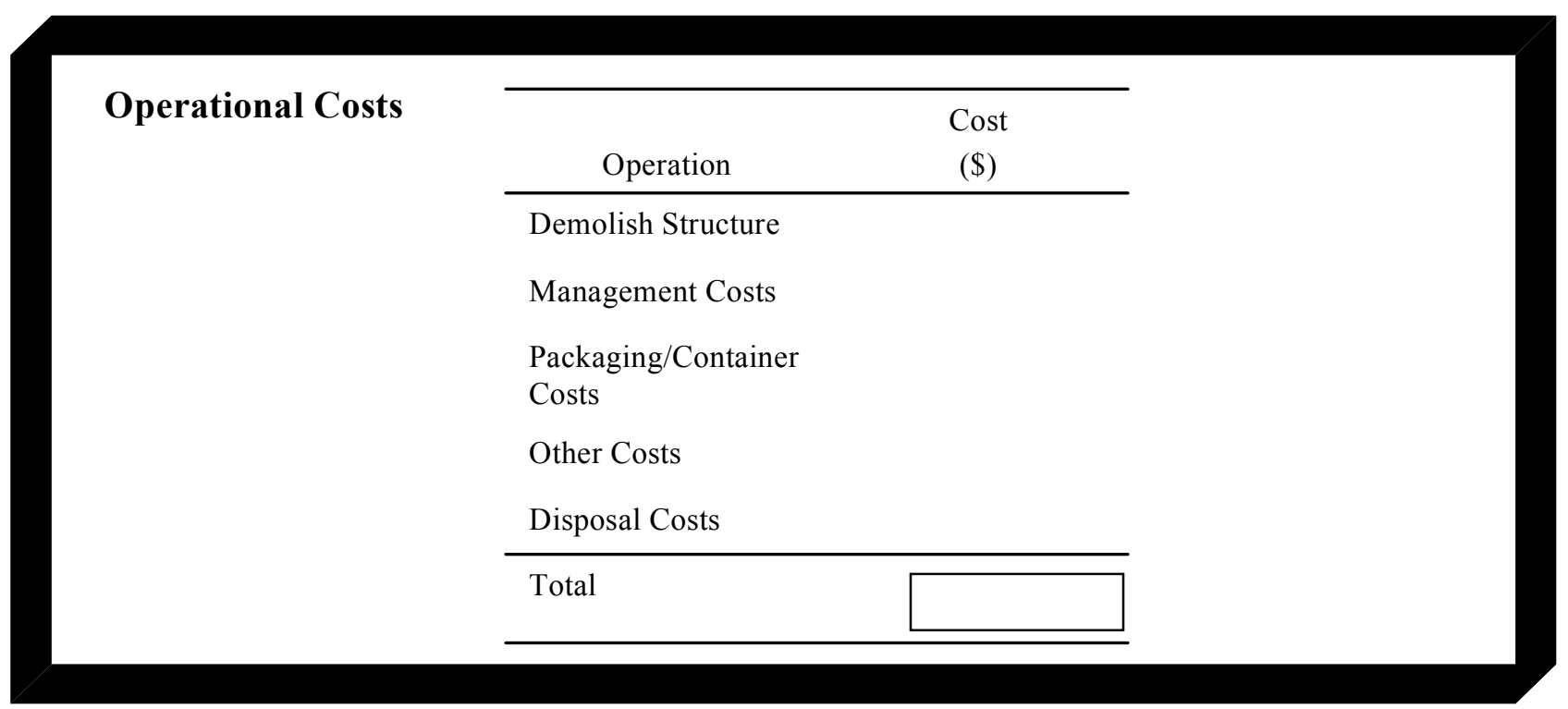




\section{Step 4. Develop Release Limits (Chapter 2, Section 2.4.3)}

\section{Alternative C}

Decontaminate the concrete material, dispose of all low-level waste (LLW), demolish the structure, and dispose the concrete material at a nonradiological landfill or reuse as backfill material

$\mathrm{C}_{-} \mathrm{c}$

\section{Transportation Costs}

Origin

Destination \# of Shipments

Distance $(\mathrm{km})$

Cost

\begin{tabular}{lllll} 
Origin & Destination $\quad$ \# of Shipments & Distance $(\mathrm{km})$ & $(\$)$ \\
\hline Total &
\end{tabular}

$\mathrm{C}_{-} \mathrm{d}$

Transportation Impacts

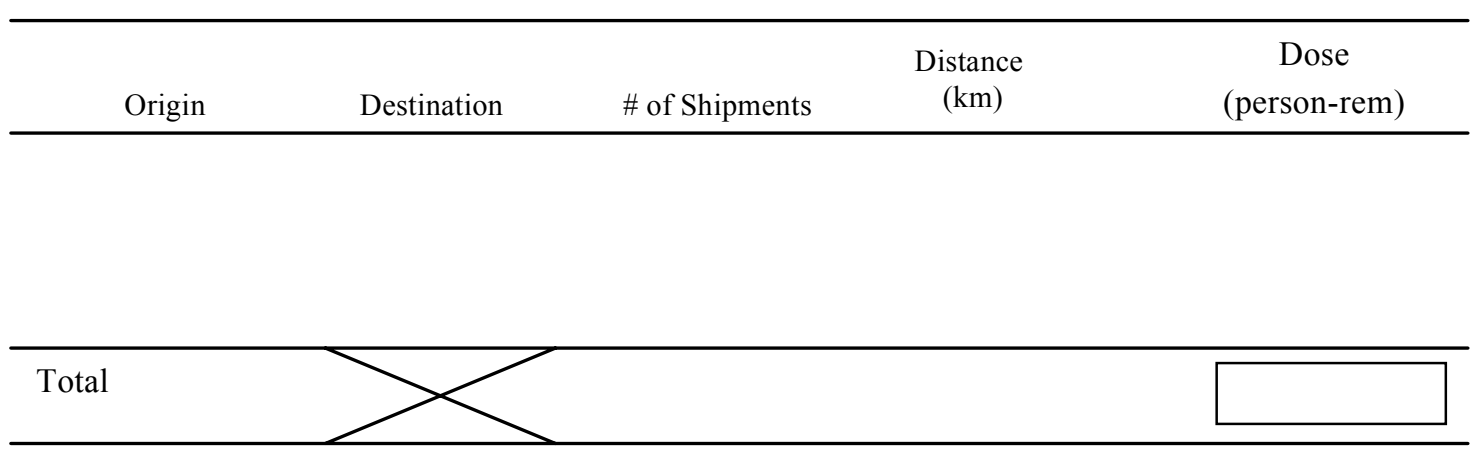




\section{Step 4. Develop Release Limits (Chapter 2, Section 2.4.3)}

\section{Alternative C}

Decontaminate the concrete material, dispose of all low-level waste (LLW), demolish the structure, and dispose the concrete material at a nonradiological landfill or reuse as backfill material

C_e

Concrete Disposal

Concentration

(pCi/g or DPM/100 $\mathrm{cm}^{2}$ )

Dose (mrem)

\begin{tabular}{|c|c|c|c|c|c|}
\hline \multirow[b]{2}{*}{ Receptor } & \multirow[b]{2}{*}{ Isotope } & \multicolumn{2}{|c|}{$\left(\mathrm{pCi} / \mathrm{g}\right.$ or $\left.\mathrm{DPM} / 100 \mathrm{~cm}^{2}\right)$} & \multicolumn{2}{|c|}{ Dose (mrem) } \\
\hline & & Average & Maximum & Average & Maximum \\
\hline
\end{tabular}

Driver

Total

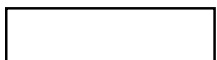

Landfill

Worker 


\section{Step 4. Develop Release Limits (Chapter 2, Section 2.4.4)}

\section{Alternative D}

Demolish the structure and dispose the concrete material at a nonradiological landfill or reuse as backfill material

D_a

\begin{tabular}{|c|c|c|}
\hline \multirow[t]{7}{*}{ Operational Costs } & Operation & $\begin{array}{l}\text { Cost } \\
(\$)\end{array}$ \\
\hline & Demolish Structure & \\
\hline & Management Costs & \\
\hline & $\begin{array}{l}\text { Packaging/Container } \\
\text { Costs }\end{array}$ & \\
\hline & Disposal Costs & \\
\hline & Other Costs & \\
\hline & Total & \\
\hline
\end{tabular}




\section{Step 4. Develop Release Limits (Chapter 2, Section 2.4.4)}

\section{Alternative D (Cont.)}

Demolish the structure and dispose the concrete material at a nonradiological landfill or reuse as backfill material

D_b

\section{Transportation Costs}

\begin{tabular}{|c|c|c|c|c|}
\hline Origin & Destination & \# of Shipments & $\begin{array}{c}\text { Distance } \\
(\mathrm{km})\end{array}$ & $\begin{array}{c}\text { Cost } \\
(\$)\end{array}$ \\
\hline
\end{tabular}

Total

D_c

Transportation Impacts

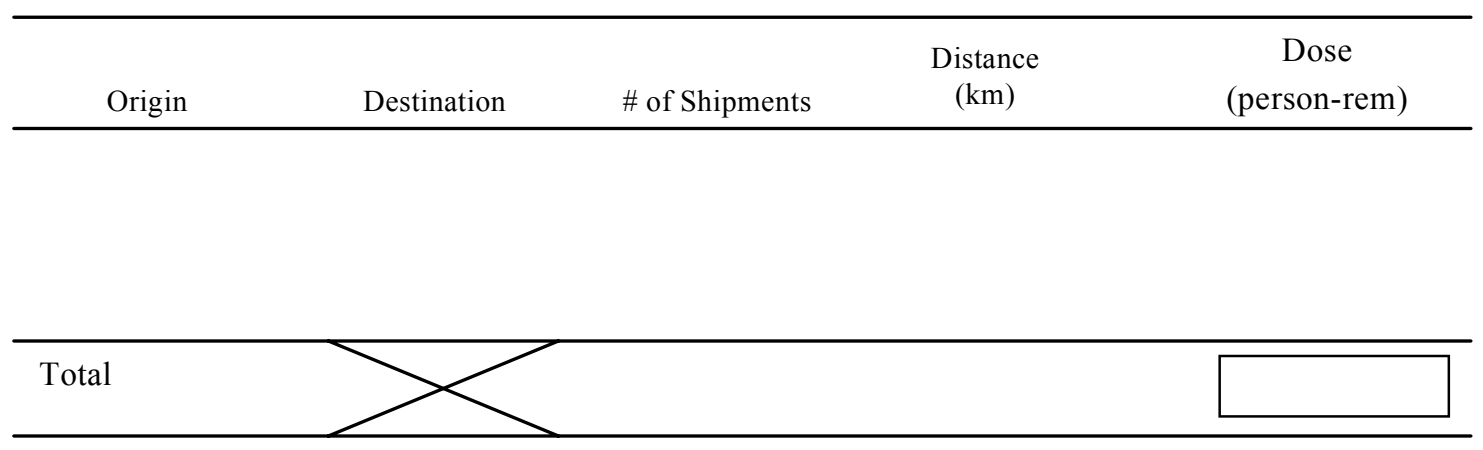




\section{Step 4. Develop Release Limits (Chapter 2, Section 2.4.2)}

\section{Alternative D (Cont.)}

Demolish the structure and dispose the concrete material at a nonradiological landfill or reuse as backfill material

D_d

\section{Concrete Disposal}

\begin{tabular}{|c|c|c|c|c|c|}
\hline \multirow[b]{2}{*}{ Receptor } & \multirow[b]{2}{*}{ Isotope } & \multicolumn{2}{|c|}{$\begin{array}{c}\text { Concentration } \\
\left(\mathrm{pCi} / \mathrm{g} \text { or } \mathrm{DPM} / 100 \mathrm{~cm}^{2}\right)\end{array}$} & \multicolumn{2}{|c|}{ Dose (mrem) } \\
\hline & & Average & Maximum & Average & Maximum \\
\hline
\end{tabular}

Driver

Total

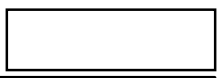

Landfill

Worker 


\section{Step 4. Develop Release Limits (Chapter 2, Section 2.4.4)}

\section{Alternative D (Cont.)}

Demolish the structure and dispose the concrete material at a nonradiological landfill or reuse as backfill material

D_e

Disposal-Future Resident

\begin{tabular}{|c|c|c|c|c|}
\hline \multirow[b]{2}{*}{ Isotope } & \multicolumn{2}{|c|}{$\begin{array}{c}\text { Concentration } \\
\left(\mathrm{pCi} / \mathrm{g} \text { or } \mathrm{DPM} / 100 \mathrm{~cm}^{2}\right)\end{array}$} & \multicolumn{2}{|c|}{ Dose (mrem) } \\
\hline & Average & Maximum & Average & Maximum \\
\hline
\end{tabular}

Stop [If last alternative proceed to Step 4, box 4c. If want to analyze another alternative see Chapter 2, Section 2.4] 


\section{Step 4. Develop Release Limits (Chapter 2, Section 2.4.5)}

Alternative E

Demolish the structure and dispose the concrete material at a low-level waste facility

E_a

Operational Costs

\begin{tabular}{lc}
\hline \multicolumn{1}{c}{ Operation } & $\begin{array}{c}\text { Cost } \\
(\$)\end{array}$ \\
\hline Demolish Structure & \\
Management Costs & \\
Packaging/Container \\
Costs \\
Disposal Costs \\
Other Costs \\
\hline Total \\
\hline
\end{tabular}




\section{Step 4. Develop Release Limits (Chapter 2, Section 2.4.5)}

\section{Alternative E (Cont.)}

Demolish the structure and dispose the concrete material at a low-level waste facility

E b

Transportation Costs

\begin{tabular}{|c|c|c|c|c|}
\hline Origin & Destination & \# of Shipments & $\begin{array}{c}\text { Distance } \\
(\mathrm{km})\end{array}$ & $\begin{array}{c}\text { Cost } \\
(\$)\end{array}$ \\
\hline
\end{tabular}

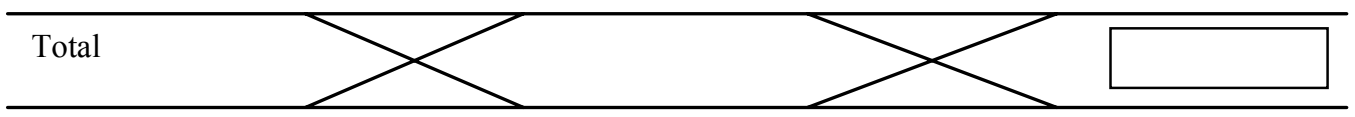

E_c

Transportation Impacts

\begin{tabular}{|c|c|c|c|c|}
\hline Origin & Destination & \# of Shipments & $\begin{array}{l}\text { Distance } \\
\quad(\mathrm{km})\end{array}$ & $\begin{array}{c}\text { Dose } \\
\text { (person-rem) }\end{array}$ \\
\hline
\end{tabular}

Total

Stop [If last alternative proceed to Step 4, box 4c. If want to analyze another alternative See Chapter 2, Section 2.4] 


\section{Step 4. Develop Release Limits (Chapter 2, Section 2.4.6)}

Alternative F

Decontaminate and reuse the building as an office

$\mathrm{F}_{-} \mathrm{a}$

Decontamination Method(s)

\begin{tabular}{cccc}
\hline $\begin{array}{c}\text { Decontamination } \\
\text { Method }\end{array}$ & $\begin{array}{c}\text { Decontamination } \\
\text { Factor }\end{array}$ & $\begin{array}{c}\text { Waste Generation } \\
\left(\mathrm{ft}^{3}\right)\end{array}$ & $\begin{array}{c}\text { Cost } \\
(\$)\end{array}$ \\
\hline & & \\
\hline Total & \\
\hline
\end{tabular}

F_b

Transportation Costs

\begin{tabular}{|c|c|c|c|c|}
\hline Origin & Destination & \# of Shipments & $\begin{array}{c}\text { Distance } \\
(\mathrm{km})\end{array}$ & $\begin{array}{l}\text { Cost } \\
(\$)\end{array}$ \\
\hline
\end{tabular}

$><+\square$

Go to Next Page 


\section{Step 4. Develop Release Limits (Chapter 2, Section 2.4.6)}

Alternative F (Cont.)

Decontaminate and reuse the building as an office

$\mathrm{F}_{-} \mathrm{c}$

Transportation Impacts

\begin{tabular}{|c|c|c|c|c|}
\hline Origin & Destination & \# of Shipments & $\begin{array}{l}\text { Distance } \\
\qquad(\mathrm{km})\end{array}$ & $\begin{array}{c}\text { Dose } \\
\text { (person-rem) }\end{array}$ \\
\hline
\end{tabular}

Total

Go to Next Page 


\section{Step 4. Develop Release Limits (Chapter 2, Section 2.4.6)}

Alternative F (Cont.)

Decontaminate and reuse the building as an office

F_d

Concrete Reuse-Impacts

\begin{tabular}{lllll}
\hline & \multicolumn{2}{c}{$\begin{array}{c}\text { Concentration } \\
\left(\mathrm{pCi} / \mathrm{g} \text { or DPM } / 100 \mathrm{~cm}^{2}\right)\end{array}$} & & \multicolumn{2}{c}{ Dose (mrem) } \\
\cline { 2 - 3 } Isotope & Average & Maximum & Average & Maximum \\
\hline
\end{tabular}


Step 4. Develop Release Limits (Chapter 2, Section 2.4.7)

Alternative G

The concrete structure will be demolished and entombed on-site

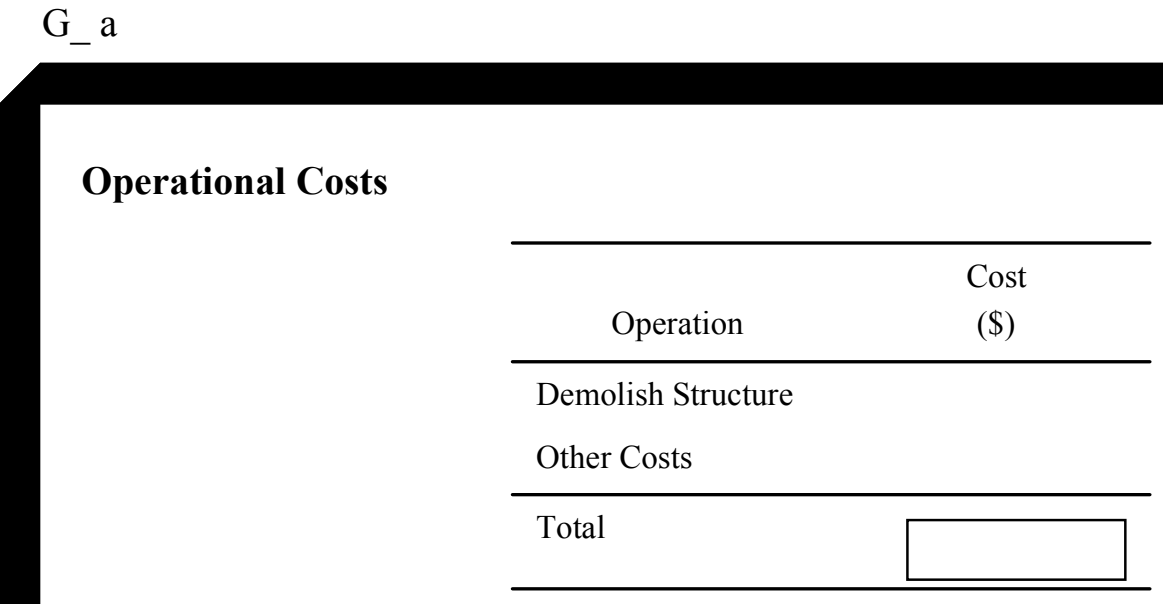




\section{Step 4. Develop Release Limits (Chapter 2, Section 2.4.7)}

\section{Alternative G (Cont.)}

The concrete structure will be demolished and entombed on-site

G_b

Disposal-Future Resident

\begin{tabular}{|c|c|c|c|c|}
\hline \multirow[b]{2}{*}{ Isotope } & \multicolumn{2}{|c|}{$\begin{array}{c}\text { Concentration } \\
\left(\mathrm{pCi} / \mathrm{g} \text { or } \mathrm{DPM} / 100 \mathrm{~cm}^{2}\right)\end{array}$} & \multicolumn{2}{|c|}{ Dose (mrem) } \\
\hline & Average & Maximum & Average & Maximum \\
\hline
\end{tabular}


Step 4. Develop Release Limits (Chapter 2, Section 2.4.8)

4c Summary of Alternatives

\begin{tabular}{|c|c|c|c|c|c|}
\hline \multicolumn{6}{|c|}{ Summary of Costs/Radiological Impacts } \\
\hline \multirow[b]{2}{*}{ Alternative } & \multicolumn{2}{|c|}{ Costs } & \multicolumn{3}{|c|}{ Dose } \\
\hline & Operational & Transportation & Transportation & Worker & $\begin{array}{l}\text { Future } \\
\text { Resident }\end{array}$ \\
\hline
\end{tabular}

Go to Next Page 
Step 4. Develop Release Limits (Chapter 2, Section 2.4.9)

4d Proposed Authorized Release Limits

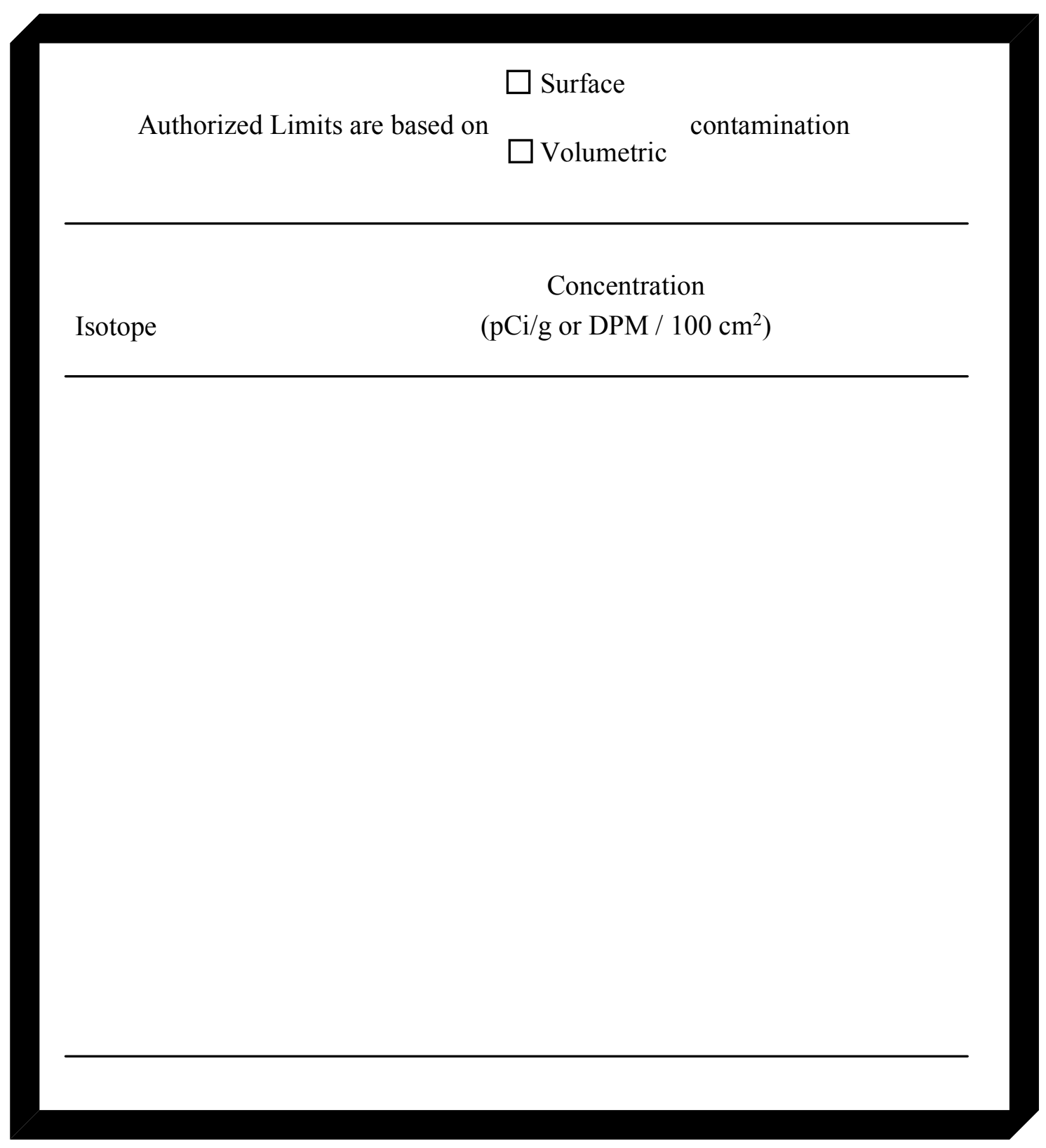

Go to Next Page 
Step 5. Compile and Submit Application for DOE Operations Approval (Chapter 2, Sections 2.4.9 and 2.5)

5a Restrictions on use following release (if applicable)

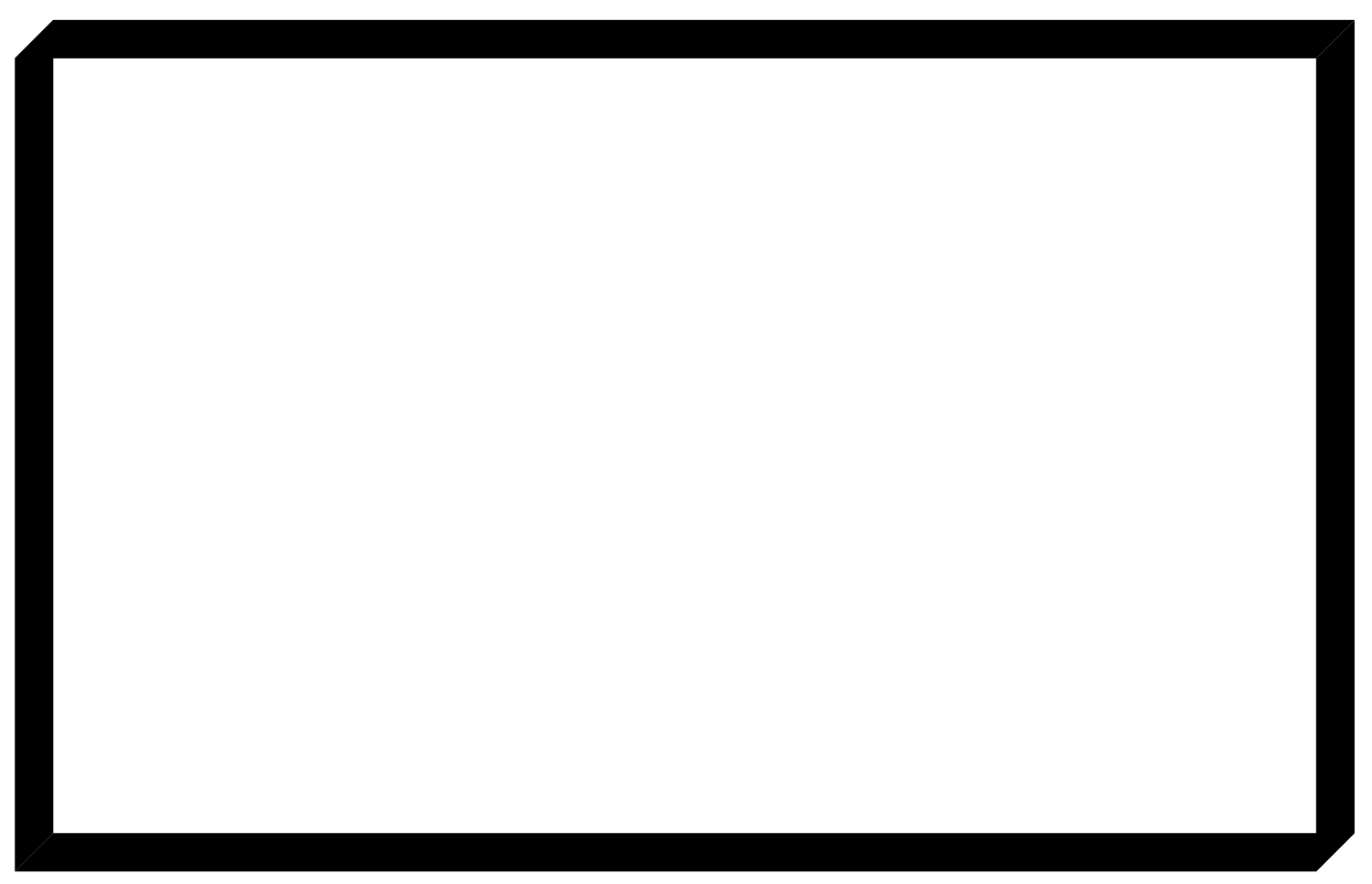

Go to Next Page 
Step 5. Compile and Submit Application for DOE Operations Approval (Chapter 2, Section 2.5)

$5 b$

Comments/Recommendations by other state or federal agencies (attach documents) 
Step 5. Compile and Submit Application for DOE Operations Approval (Chapter 2, Section 2.8)

$5 c$

Survey Protocols (attach applicable documents) 
APPENDIX B:

DECONTAMINATION MODULE 


$$
\text { B-2 }
$$


TABLE B.1 Common Decontamination Technologies with Unit-Cost and Process Factors for Removal of "Loose" Contamination

\begin{tabular}{|c|c|c|c|c|}
\hline Technology & $\begin{array}{c}\text { Capital Cost } \\
(\$ 1,000)\end{array}$ & $\begin{array}{l}\text { Production } \\
\text { Rate }\left(\mathrm{ft}^{2} / \mathrm{h}\right) \\
\end{array}$ & $\begin{array}{l}\text { Estimated Cost } \\
\left(\$ / \mathrm{ft}^{2} \text { cleaned }\right)\end{array}$ & Secondary Waste Generation \\
\hline $\mathrm{CO}_{2}$ pellet blasting & $150-350$ & $10-90$ & $0.90-1.75$ & $\begin{array}{l}\text { Low - filters from HEPA } \\
\text { systems }\end{array}$ \\
\hline Water/steam blasting & 50 & Variable & $0.50-2$ & $\begin{array}{l}\text { High - large volumes of water } \\
\text { to clean/process }\end{array}$ \\
\hline $\begin{array}{l}\text { Hand scrubbing (with spray on } \\
\text { chemicals) }\end{array}$ & Low & $\begin{array}{l}\text { Variable } \\
(10-100)\end{array}$ & 82 & Low \\
\hline Strippable coatings & Low & Up to 100 & $1-1.40$ & Low \\
\hline Abrasive blasting with soft grits & $50-200$ & $60-200$ & $0.20-2.15$ & $10-50 \mathrm{ft}^{3} / \mathrm{ft}^{2}$ \\
\hline
\end{tabular}

TABLE B.2 Common Technologies for Removing "Fixed" and Subsurface Contamination from Concrete (removal of 1/16- to 1/2-in. layers of concrete)

\begin{tabular}{|c|c|c|c|c|c|}
\hline Technology & $\begin{array}{c}\text { Capital } \\
\text { Cost } \\
(\$ 1,000) \\
\end{array}$ & $\begin{array}{c}\text { Production } \\
\text { Rate } \\
\left(\mathrm{ft}^{2} / \mathrm{h} / \text { pass }\right)\end{array}$ & $\begin{array}{c}\text { Process cost } \\
\left(\$ / \mathrm{ft}^{2} / \text { pass }\right)\end{array}$ & $\begin{array}{c}\text { Removal } \\
\text { Rate } \\
\text { (in./pass) }\end{array}$ & Waste Generation \\
\hline $\begin{array}{l}\text { Abrasive blasting with } \\
\text { aggressive grits }\end{array}$ & $50-300$ & $50-400$ & $5-10$ & $1 / 16$ & $\begin{array}{l}0.03 \mathrm{ft}^{3} \text { solids } / \mathrm{ft}^{2} \text { cleaned } \\
+ \text { concrete removed }\end{array}$ \\
\hline $\begin{array}{l}\text { Hand held scarification/ } \\
\text { scabbling }\end{array}$ & 5 & $10-30$ & $1.85-2.50$ & $1 / 16-1 / 4$ & Concrete removed \\
\hline Automated floor scabbling & $30-175$ & $20-400$ & $5-30$ & $1 / 16-1 / 2$ & Concrete removed \\
\hline Automated wall scabbling & $100-300$ & $60-200$ & $10-30$ & $1 / 16-1 / 4$ & $\begin{array}{l}\text { Concrete removed, if water } \\
\text { used up to } 6 \mathrm{gal} / \mathrm{min} \\
\text { recycled. }\end{array}$ \\
\hline Shot blasting & $30-150$ & 420 & $50-400$ & $1 / 4$ & $0.01-0.19 \mathrm{ft}^{3} / \mathrm{ft}^{2}$ \\
\hline
\end{tabular}


APPENDIX C:

TRANSPORTATION UNIT-COST AND DOSE FACTORS 


$$
\text { C-2 }
$$


TABLE C.1 Volumes and Unit Costs for Selected Cargo Containers

\begin{tabular}{cccc}
\hline Container Type & $\begin{array}{c}\text { Container } \\
\text { Volume } \\
\left(\mathrm{ft}^{3}\right)\end{array}$ & $\begin{array}{c}\text { Container } \\
\text { Cost }(\$)\end{array}$ & $\begin{array}{c}\text { Unit Loading } \\
\text { Cost }(\$)\end{array}$ \\
\hline B-25 type box ${ }^{\text {a }}$ & 87 & 790 & 160 \\
Soft-sided container $^{\text {55-gal drum }}{ }^{\text {a }}$ & 260 & 500 & 301 \\
\hline
\end{tabular}

${ }^{\text {a }}$ Source: Chen et al. (1996).

TABLE C.2 Unit Costs for Concrete Shipments as a Function of Cargo and Transportation Mode

\begin{tabular}{lcccr}
\hline \multicolumn{1}{c}{ Cargo Shipped } & $\begin{array}{c}\text { Transportation } \\
\text { Mode }\end{array}$ & $\begin{array}{c}\text { Fixed Cost per } \\
\text { Shipment (\$) }\end{array}$ & $\begin{array}{c}\text { Variable Cost } \\
\text { per Shipment- } \\
\text { Mile (\$) }\end{array}$ & $\begin{array}{c}\text { Applicable } \\
\text { Mileage }\end{array}$ \\
\hline $\begin{array}{l}\text { Concrete in B-25 type } \\
\text { or soft-sided boxes }\end{array}$ & Truck & 335 & 1.43 & $0-9,999$ \\
& Rail & 750 & 2.32 & $0-1,000$ \\
& & & 1.91 & $1,000-2,000$ \\
Waste in drums & Truck & & 1.60 & $2,000-9,999$ \\
& Rail & 750 & $4.00-5.94$ & $0-9,999$ \\
& & & 2.32 & $0-1,000$ \\
& & & 1.91 & $1,000-2,000$ \\
& & & 1.60 & $2,000-9,999$ \\
\hline
\end{tabular}

Source: Chen et al. (1996). 
TABLE C.3 Unit-Dose Factors ${ }^{\mathrm{a}}$ from the Transportation Module for the Driver and Persons Living along (off-link) or Sharing (on-link) the Transportation Corridor

\begin{tabular}{|c|c|c|}
\hline Radionuclide & $\begin{array}{c}\text { Driver Dose } \\
(\mathrm{mrem} / \mathrm{pCi} / \mathrm{km})\end{array}$ & $\begin{array}{c}\text { Collective Dose } \\
\text { (person-rem } / \mathrm{pCi} / \mathrm{km} \text { ) }\end{array}$ \\
\hline Ac- $227+D^{b}$ & $4.1 \mathrm{E}-14$ & $1.24 \mathrm{E}-17$ \\
\hline Ag-108m & $2 \mathrm{E}-13$ & $6.22 \mathrm{E}-17$ \\
\hline Ag-110m & $3.5 \mathrm{E}-13$ & $1.10 \mathrm{E}-16$ \\
\hline Am-241 & $2.3 \mathrm{E}-16$ & $3.41 \mathrm{E}-20$ \\
\hline Ce-144+D & $6.4 \mathrm{E}-15$ & $1.96 \mathrm{E}-18$ \\
\hline Co-57 & $9.6 \mathrm{E}-15$ & $2.81 \mathrm{E}-18$ \\
\hline Co- 60 & $3.3 \mathrm{E}-13$ & $1.04 \mathrm{E}-16$ \\
\hline Cs-134 & $1.9 \mathrm{E}-13$ & $6.01 \mathrm{E}-17$ \\
\hline Cs $-137+D$ & $7.0 \mathrm{E}-14$ & $2.21 \mathrm{E}-17$ \\
\hline Eu-152 & $1.4 \mathrm{E}-13$ & $4.41 \mathrm{E}-17$ \\
\hline Eu-154 & $1.5 \mathrm{E}-13$ & $4.81 \mathrm{E}-17$ \\
\hline Eu-155 & $2.3 \mathrm{E}-15$ & $5.61 \mathrm{E}-19$ \\
\hline $\mathrm{Fe}-55$ & $0.00 \mathrm{E}+00$ & $0.00 \mathrm{E}+00$ \\
\hline I-129 & $1.0 \mathrm{E}-20$ & $1.16 \mathrm{E}-27$ \\
\hline $\mathrm{Mn}-54$ & $1.1 \mathrm{E}-13$ & $3.21 \mathrm{E}-17$ \\
\hline Ni-63 & $0.00 \mathrm{E}+00$ & $0.00 \mathrm{E}+00$ \\
\hline $\mathrm{Np}-237+\mathrm{D}$ & $2.2 \mathrm{E}-14$ & $6.82 \mathrm{E}-18$ \\
\hline $\mathrm{Pu}-238$ & $1.7 \mathrm{E}-19$ & $1.78 \mathrm{E}-23$ \\
\hline Pu-239 & $5 \mathrm{E}-18$ & $1.54 \mathrm{E}-21$ \\
\hline $\mathrm{Pu}-240$ & $1.7 \mathrm{E}-19$ & $1.82 \mathrm{E}-23$ \\
\hline $\mathrm{Pu}-241+\mathrm{D}$ & $3.5 \mathrm{E}-19$ & $1.02 \mathrm{E}-22$ \\
\hline $\mathrm{Ra}-226+\mathrm{D}$ & $2.3 \mathrm{E}-13$ & 7.22E-17 \\
\hline Ru-106+D & $2.7 \mathrm{E}-14$ & $8.22 \mathrm{E}-18$ \\
\hline $\mathrm{Sb}-125+\mathrm{D}$ & $5.1 \mathrm{E}-14$ & $1.58 \mathrm{E}-17$ \\
\hline Sr-90 & $0.00 \mathrm{E}+00$ & $0.00 \mathrm{E}+00$ \\
\hline Tc-99 & $1.8 \mathrm{E}-18$ & $5.01 \mathrm{E}-22$ \\
\hline Th-230 & $1.7 \mathrm{E}-17$ & $4.41 \mathrm{E}-21$ \\
\hline $\mathrm{U}-232$ & $1.2 \mathrm{E}-17$ & $3.01 \mathrm{E}-21$ \\
\hline U-233 & $2.7 \mathrm{E}-17$ & $8.22 \mathrm{E}-21$ \\
\hline U-234 & $3.5 \mathrm{E}-18$ & 7.62E-22 \\
\hline $\mathrm{U}-235+\mathrm{D}$ & $1.5 \mathrm{E}-14$ & $4.61 \mathrm{E}-18$ \\
\hline $\mathrm{U}-238+\mathrm{D}$ & $2.6 \mathrm{E}-15$ & $7.82 \mathrm{E}-19$ \\
\hline $\mathrm{Zn}-65$ & $7.5 \mathrm{E}-14$ & $2.41 \mathrm{E}-17$ \\
\hline
\end{tabular}

aThe unit-dose factors for the driver and the collective dose factors for the persons living along the or sharing the transportation corridor are calculated using TSD-DOSE (Pfingston et al. 1998) and RISKIND (Yuan et al. 1995) computer codes.

b“" $+\mathrm{D}$ ” means progeny nuclides with half-lives less than 180 days are in secular equilibrium with the parent. 
APPENDIX D:

REUSE MODULE UNIT-DOSE FACTORS 


$$
\text { D-2 }
$$


TABLE D.1 Unit-Dose Factors ${ }^{\mathrm{a}}$ for the Construction Worker and Building Resident from the Reuse Module

\begin{tabular}{|c|c|c|}
\hline Radionuclide & $\begin{array}{l}\text { Construction Worker } \\
(\mathrm{mrem} / \mathrm{yr} / \mathrm{pCi} / \mathrm{g} / \text { ton })\end{array}$ & $\begin{array}{l}\text { Building Resident } \\
\left(\mathrm{mrem} / \mathrm{yr} / \mathrm{pCi} / \mathrm{m}^{2}\right)\end{array}$ \\
\hline Ac- $-227+D^{b}$ & 2.44E-04 & $2.62 \mathrm{E}-02$ \\
\hline Ag-108m & $\mathrm{NA}^{\mathrm{c}}$ & $1.43 \mathrm{E}-05$ \\
\hline Ag-110m & 2.37E-04 & $1.42 \mathrm{E}-05$ \\
\hline Am-241 & $1.85 \mathrm{E}-05$ & $1.84 \mathrm{E}-03$ \\
\hline Ce-144+D & $4.51 \mathrm{E}-06$ & $6.99 \mathrm{E}-07$ \\
\hline Co-57 & $6.49 \mathrm{E}-06$ & $5.57 \mathrm{E}-07$ \\
\hline Co-60 & $3.26 \mathrm{E}-04$ & $1.90 \mathrm{E}-05$ \\
\hline Cs-134 & $1.78 \mathrm{E}-04$ & $1.12 \mathrm{E}-05$ \\
\hline Cs-137+D & 7.47E-05 & $5.16 \mathrm{E}-06$ \\
\hline Eu-152 & $1.48 \mathrm{E}-04$ & $9.82 \mathrm{E}-06$ \\
\hline Eu-154 & $1.60 \mathrm{E}-04$ & $1.05 \mathrm{E}-05$ \\
\hline Eu-155 & NA & $5.98 \mathrm{E}-07$ \\
\hline $\mathrm{Fe}-55$ & $9.38 \mathrm{E}-10$ & $1.20 \mathrm{E}-08$ \\
\hline $\mathrm{I}-129$ & NA & 4.12E-06 \\
\hline $\mathrm{Mn}-54$ & $7.75 \mathrm{E}-05$ & 4.70E-06 \\
\hline $\mathrm{Ni}-63$ & $1.11 \mathrm{E}-09$ & $3.15 \mathrm{E}-08$ \\
\hline Np-237+D & 4.56E-05 & $2.25 \mathrm{E}-03$ \\
\hline $\mathrm{Pu}-238$ & $1.57 \mathrm{E}-05$ & $1.61 \mathrm{E}-03$ \\
\hline Pu-239 & $1.73 \mathrm{E}-05$ & $1.79 \mathrm{E}-03$ \\
\hline $\mathrm{Pu}-240$ & $1.73 \mathrm{E}-05$ & $1.79 \mathrm{E}-03$ \\
\hline $\mathrm{Pu}-241+\mathrm{D}$ & $3.25 \mathrm{E}-07$ & $3.18 \mathrm{E}-05$ \\
\hline $\mathrm{Ra}-226+\mathrm{D}$ & $2.44 \mathrm{E}-04$ & $6.67 \mathrm{E}-05$ \\
\hline Ru-106+D & $2.07 \mathrm{E}-05$ & 2.19E-06 \\
\hline $\mathrm{Sb}-125+\mathrm{D}$ & $4.83 \mathrm{E}-05$ & $3.25 \mathrm{E}-06$ \\
\hline Sr-90 & $7.47 \mathrm{E}-07$ & $6.85 \mathrm{E}-06$ \\
\hline Tc-99 & 4.99E-09 & $5.02 \mathrm{E}-08$ \\
\hline Th-230 & $9.63 \mathrm{E}-06$ & $1.33 \mathrm{E}-03$ \\
\hline U-232 & $1.97 \mathrm{E}-05$ & $2.81 \mathrm{E}-03$ \\
\hline $\mathrm{U}-233$ & 4.13E-06 & $5.53 \mathrm{E}-04$ \\
\hline $\mathrm{U}-234$ & $4.01 \mathrm{E}-06$ & 5.39E-04 \\
\hline $\mathrm{U}-235+\mathrm{D}$ & $1.99 \mathrm{E}-05$ & $5.07 \mathrm{E}-04$ \\
\hline $\mathrm{U}-238+\mathrm{D}$ & $6.44 \mathrm{E}-04$ & 4.84E-04 \\
\hline Zn-65 & $5.01 \mathrm{E}-05$ & $2.97 \mathrm{E}-06$ \\
\hline \multicolumn{3}{|c|}{$\begin{array}{l}\text { The unit-dose factors for the construction worker and the } \\
\text { building resident are calculated using the RESRAD-RECYCLE } \\
\text { (Cheng et al. 1999) and RESRAD-BUILD (Yu et al. 1994) } \\
\text { computer codes. }\end{array}$} \\
\hline \multicolumn{3}{|c|}{$\begin{array}{l}\text { b " }+\mathrm{D} \text { ” means progeny nuclides with half-lives less than } \\
180 \text { days are in secular equilibrium with the parent. }\end{array}$} \\
\hline
\end{tabular}


APPENDIX E:

DISPOSAL MODULE UNIT-DOSE FACTORS 


$$
\text { E-2 }
$$


TABLE E.1 Unit-Dose Factors ${ }^{\text {a }}$ for the Landfill Worker (nonradiological landfill disposal alternative) and Future Resident (nonradiological landfill and entombment)

\begin{tabular}{|c|c|c|}
\hline Radionuclide & $\begin{array}{l}\text { Landfill Worker } \\
(\mathrm{mrem} / \mathrm{pCi})\end{array}$ & $\begin{array}{c}\text { Future Resident } \\
\text { (mrem/yr/pCi/g/ton) }\end{array}$ \\
\hline Ac- $227+D^{b}$ & $9.9 \mathrm{E}-11$ & $3.18 \mathrm{E}-04$ \\
\hline Ag-108m & $4 \mathrm{E}-12$ & $3.21 \mathrm{E}-04$ \\
\hline Ag-110m & $7.1 \mathrm{E}-12$ & 2.24E-04 \\
\hline Am-241 & $6.5 \mathrm{E}-12$ & 7.29E-04 \\
\hline Ce-144+D & $1.3 \mathrm{E}-13$ & 7.69E-06 \\
\hline Co-57 & $1.7 \mathrm{E}-13$ & $1.22 \mathrm{E}-05$ \\
\hline Co-60 & $6.7 \mathrm{E}-12$ & $5.53 \mathrm{E}-04$ \\
\hline Cs-134 & $3.9 \mathrm{E}-12$ & $3.12 \mathrm{E}-04$ \\
\hline Cs- $137+D$ & $1.4 \mathrm{E}-12$ & $1.42 \mathrm{E}-04$ \\
\hline Eu-152 & $2.9 \mathrm{E}-12$ & $2.41 \mathrm{E}-04$ \\
\hline Eu-154 & $3.1 \mathrm{E}-12$ & $2.61 \mathrm{E}-04$ \\
\hline Eu-155 & $2.9 \mathrm{E}-14$ & 6.17E-06 \\
\hline $\mathrm{Fe}-55$ & $3.9 \mathrm{E}-17$ & $1.61 \mathrm{E}-08$ \\
\hline $\mathrm{I}-129$ & $2.5 \mathrm{E}-15$ & $7.06 \mathrm{E}-03$ \\
\hline $\mathrm{Mn}-54$ & $2.1 \mathrm{E}-12$ & $1.28 \mathrm{E}-04$ \\
\hline $\mathrm{Ni}-63$ & $9.2 \mathrm{E}-17$ & 2.87E-07 \\
\hline Np-237+D & $8.3 \mathrm{E}-12$ & $5.48 \mathrm{E}-04$ \\
\hline $\mathrm{Pu}-238$ & $5.7 \mathrm{E}-12$ & $2.47 \mathrm{E}-05$ \\
\hline $\mathrm{Pu}-239$ & $6.3 \mathrm{E}-12$ & $2.75 \mathrm{E}-05$ \\
\hline $\mathrm{Pu}-240$ & $6.3 \mathrm{E}-12$ & $2.75 \mathrm{E}-05$ \\
\hline $\mathrm{Pu}-241+\mathrm{D}$ & $1.2 \mathrm{E}-13$ & $2.35 \mathrm{E}-05$ \\
\hline $\mathrm{Ra}-226+\mathrm{D}$ & 4.7E-12 & $4.38 \mathrm{E}-03$ \\
\hline Ru-106+D & $5.4 \mathrm{E}-13$ & $1.23 \mathrm{E}-04$ \\
\hline $\mathrm{Sb}-125+\mathrm{D}$ & $1 \mathrm{E}-12$ & 4.63E-05 \\
\hline Sr-90 & $1.9 \mathrm{E}-14$ & $3.12 \mathrm{E}-04$ \\
\hline Tc-99 & $1.5 \mathrm{E}-16$ & $4.08 \mathrm{E}-05$ \\
\hline Th-230 & $4.8 \mathrm{E}-12$ & $7.80 \mathrm{E}-04$ \\
\hline $\mathrm{U}-232$ & $9.6 \mathrm{E}-12$ & $9.41 \mathrm{E}-05$ \\
\hline U-233 & $2 \mathrm{E}-12$ & 7.95E-06 \\
\hline U-234 & $1.9 \mathrm{E}-12$ & $5.40 \mathrm{E}-06$ \\
\hline $\mathrm{U}-235+\mathrm{D}$ & $2.1 \mathrm{E}-12$ & $9.43 \mathrm{E}-05$ \\
\hline $\mathrm{U}-238+\mathrm{D}$ & $1.8 \mathrm{E}-12$ & 3.33E-05 \\
\hline $\mathrm{Zn}-65$ & $1.5 \mathrm{E}-12$ & $9.69 \mathrm{E}-05$ \\
\hline
\end{tabular}

a The unit dose factors for the landfill worker and future resident are calculated using the TSD-DOSE (Pfingston et al. 1998) and RESRAD (Yu et al. 1993) computer codes.

b " $+\mathrm{D}$ " means progeny nuclides with half-lives less than 180 days are in secular equilibrium with the parent. 


$$
\text { E-4 }
$$

